\title{
TEXTILIE Z HROBU NACHÁZEJÍCÍHO SE JIŽNĚ OD HROBU PETRA PARLÉŘE V KATEDRÁLE SV. VÍTA NA PRAŽSKÉM HRADĚ
}

\author{
MILENA BRAVERMANOVÁ - JAN VLČEK - ROMANA KLOUDOVÁ - ALŽBĚTA \\ VRABCOVÁ $^{1}$
}

\begin{abstract}
Abstrakt: Roku 1928 byly v rámci dostavby katedrály sv. Vita nalezeny hroby jejich prvnich stavitelü, Matyáše z Arrasu a Petra Parlére. V jejich těsné blizkosti se zároveñ nacházel i hrob neznámé osoby, z něhož byly vyjmuty fragmenty luxusnich tkanin. Poté se na objev na téměr 90 let zapomnělo, teprve v nedávné době došlo v depozitáři na Pražském hradě kjeho úspěšnému restaurování a interpretaci. Pravděpodobně se jedná o obsah hrobu vysokého cirkevního představitele, pohřbeného okolo přelomu 14. a 15. století v mimořádné bohaté pohřební výbavě. Dochovaly se pozůstatky hedvábné punčochy a kožené boty a dále fragmenty látek určitelné jako pozůstatky kasule, alby zdobené výšivkami a mitry pošité zlatými zdobenými tkanicemi. Na základě zjištěných poznatků je možné hrob hypoteticky připsat zvolenému pražskému arcibiskupu Mikuláši Puchnikovi († 1402).
\end{abstract}

Klíčová slova: Pražský hrad - Mikuláš Puchník - Petr Parléř - lampas - punčocha - bota - výšivka archeologický textil.

\section{Fabrics from a grave located south of the grave of Petr Parlér in St. Vitus Cathedral, Prague Castle}

Abstract: Graves of the first builders of St. Vitus Cathedral, Matthias of Arras and Petr Parlér. were uncovered in the course of its completion in 1928. In their close proximity there was a grave of an unknown man which yielded fragments of luxury fabrics. After the discovery, the find was forgotten for the next 90 years, and only recently were the items successfully restored and interpreted in a Prague Castle depository. They probably come from a grave of a high church official, buried there in the late 14th century or the early 15th century with exceptionally rich grave goods. There were remains of a silk hose and a leather shoe, as well as fragments of fabrics identified as the remains of a chasuble, an alb decorated with embroidery and a mitre embellished with gold-thread cords. Based on the information, the grave can be hypothetically attributed to Prague Archbishop Mikuláš Puchnik († 1402).

Key words: Prague Castle - Mikuláš Puchnik - Petr Parlér - lampas - hose - shoe - embroidery - archaeological fabric.

\section{1 Úvod}

Na Pražském hradě se nachází unikátní kolekce archeologického textilu získaného při různých výzkumech a stavebních aktivitách, učiněných na Pražském hradě za poslední více než jedno století. Tato kolekce byla nedávno obohacena o soubor, který obsahoval pozůstatky luxusních textilií, z nichž pro některé dosud nebyly v hradních sbírkách paralely. Zajímavá je i historie objevu a interpretace celého souboru, který v nedávné minulosti prošel restaurováním (Kloudová-Vrabcová 2018).

V roce 2016 byl do archeologické sbírky Správy Pražského hradu² předán z Archeologického ústavu AV ČR, Praha, v. v. i., drobný soubor nálezů objevený při vyklízení starého sklepního depozitáře v č. p. 37 ve Vikářské ulici na Pražském hradě. Jednalo se o několik různých textilií, z nichž některé měly vytkané vzory, jiné byly vyšívané zlatými nitěmi. Dochovalo se též několik úlomků kůže, rovněž se zbytky zlacení. Fragmenty byly proloženy starými skleněnými okenními tabulkami, na jejichž okrajích se místy dochovaly zbytky sklenářského kytu. Protože v té době vrcholily př́ípravy výstavy k 700. výročí Karla IV. a s tím spojené restaurování textilií z královské

1 Za konzultace děkujeme H. Březinové.

2 Soubor je zapsán pod inv. č. PHA 223. 
hrobky v katedrále sv. Víta, byl předaný soubor uložen v depozitáři. K jeho restaurování, průzkumu a zhodnocení došlo až ke konci roku 2017.

\section{Nálezové okolnosti}

Při první podrobné prohlídce bylo shledáno, že soubor může dosahovat značného stáří, nebot' na dvou fragmentech téže látky byly zjištěny vytkávané motivy fénixů, které bylo slohově možno řadit již do 14. století. Původ a nálezové okolnosti souboru zpočátku nebyly známé, jediným vodítkem byly čtyři papírové proužky umístěné spolu s textiliemi mezi skleněnými tabulkami, na nichž bylo napsáno „Z hrobu jižně od P. P.“. V rámci úvahy se prověřovala možnost, že „P. P.“ by mohla být zkratka pro jméno Petr Parléŕ, jehož hrob byl nalezen a otevřen spolu s hrobem Matyáše z Arrasu během stavebních úprav ve svatovítské katedrále v roce 1928. Z obou hrobů bylo tehdy vyzvednuto také několik fragmentů textilií. Jejich fotografie, nacházející se v dokumentaci oddělení uměleckých sbírek Správy Pražského hradu, byly pořízeny v roce $1965 .{ }^{3}$ Je z nich zřejmé, že $\mathrm{v}$ této době byly textilie uloženy rovněž mezi skleněnými tabulkami a opatřeny popiskami psanými stejným rukopisem jako štítky u látek ,z hrobu jižně od P. P.“.

Podrobnosti $\mathrm{k}$ nálezovým okolnostem přineslo studium zápisů v deníku z dostavby katedrály, vedeném stavitelem F. X. Margoldem, ${ }^{4}$ nyní uloženém v Archivu Pražského hradu. ${ }^{5}$ V sešitu pokrývajícím období od 12. července do 30. listopadu 1928 lze nalézt i informace o objevu a výzkumu hrobů stavitelů chrámu a jejich okolí.

Roku 1928 byla v rámci dostavby katedrály opravována také podlaha $\mathrm{v}$ její staré části, která byla položena již roku 1673. Dne 6. srpna 1928 odstěhovali dělníci barokní zpovědnici stojící do té doby vedle dveři do Staré sakristie v severní části chórového ochozu. Po jejím odsunutí byly spatřeny dvě v podlaze zasazené pískovcové náhrobní desky, které byly zpovědnicí ze dvou třetin zakryty, což uchránilo na nich vyryté obrazy a nápisy před ošlapáním. Na obou deskách byly v obrysech vyryty postavy mužů, nápisy je určily jako Matyáše z Arrasu († 1352) a Petra Parlére († 1399). Pod deskou Matyáše z Arrasu byla v hloubce asi $90 \mathrm{~cm}$ nalezena stavitelova kostra, která, ač uložena $\mathrm{v}$ anatomické poloze, vykazovala znaky druhotné manipulace. To vedlo k domněnce, že Matyáš byl původně pohřben jinde a na toto místo byl jeho hrob přenesen až po smrti Petra Parléře, tak aby oba stavitelé byli pohřbeni vedle sebe a zároveň př́ímo pod svými bustami na vnitřním triforiu. Pod deskou Petra Parléře nebylo nalezeno nic. Protože ale panovalo podezření, že Parléřova deska byla přesunuta až při pokládání barokní dlažby, kopalo se jižně od Matyášova hrobu, kde byla skutečně nalezena kostra druhého stavitele. $Z$ obou hrobů byly vyzdviženy zbytky látek zdobených zlatem vytkanými motivy (Bravermanová 1999).

Po nalezení hrobů stavitelů chrámu se pokračovalo v práci v jejich nejbližším okolí a již 18. srpna 1928 byla jižně od hrobu Petra Parléře objevena další kostra. Ve stavebním deníku se o nálezu píše toto: „Vykopávka. 2 tesaři a 6 přidavačů kope. Objevili jsme širokou zed' románskou a zdivo kř́žové lodě. Nález jedné kostry, která ležela souběžně s kostrou Petra Parlére jižně. Nalez zbytků látky hedvábné a sametu. V̌̌e uloženo pod skleněné desky. Látka hedvábná má ornamenty ze zlatých nitek přišitých ve tvaru vinného listu a žaludového látka má ornament ptákủ a květů. Byly též nalezené stuhy zlatou nití ornamentálně prošivaných. Křižek neb jiný prededmèt nalezen nebyl. Nalez románských fragmentů architektonických článkủ. Neorganicky pohozené lebky a kosti v rumu.“ (Margold 1928, 754). ${ }^{6}$ Tento zápis dokládá, že textilie původně uložené v depozitáři ve Vikářské ulici byly skutečně nalezeny roku 1928 v těsném sousedství hrobu Petra Parlére. Z textu dále vyplývá, že soubor se nachází v úplnosti, nebot' všechny uvedené položky lze

\footnotetext{
3 Uloženo pod inv. č. K 448 a K 449.

4 František Xaver Margold (1887-1967) zastupoval v řízení dostavby katedrály dlouhodobě nemocného stavitele Kamila Hilberta od roku 1924. Ve starši literatuře je jako autor deníků uváděn K. Hilbert. Podle písma a s ohledem na známá fakta o posledních letech dostavby katedrály je však zřejmé, že deníky vedl F. X. Margold osobně.

5 Uloženo pod sign. A 420/2013.

6 Jedná se o doslovný přepis textu z deníku.
} 
fyzicky přiřadit ke konkrétním textiliím. Dochovaly se však i předměty, které nejsou zmíněny, například zbytky kůže. Porovnáním písma z deníků bylo možno zjistit, že texty na lístečcích nalezených spolu s látkami byly psány přímo rukou $\mathrm{F}$. X. Margolda. Výkopová zpráva z roku 1928 se nezmiňuje o žádném náhrobku, který by hrob kryl, původně ale snad existoval a posléze byl zničen.

Stará sakristie byla dokončena roku 1362 (Benešovská 1994, 37-41), pohřeb tedy nemohl proběhnout před tímto datem. Protože původní stratigrafie hrobů stavitelů chrámu a jejich okolí není známa, nelze říci, zda hrob neznámé osoby byl mladší či starší než hrob Petra Parléře. Německý historik Otto Kletzl, který se také na konci 20. let 20. století účastnil vykopávek v katedrále a který zřejmě jako jediný krátce po objevu podal zprávu o nálezu hrobů sousedících s hroby stavitelů chrámu, se domníval, že v těchto hrobech jsou pohřbeni Parléřův syn a vnuk, oba jménem Jan (Kletzl 1931, 175). Druhý zmíněný hrob je snad možno ztotožnit s některým z hrobů, které se v okolí hrobu Petra Parléře při vykopávkách našly a které jsou rovněž stručně zmíněny ve stavebním deníku.

Co se s nálezem dělo po roce 1928, není zřejmé, nebot' se nedochovaly žádné další záznamy. Podle poznámek o jiných hrobech uvedených v deníku se však zdá, že kosti byly uloženy do dřevěné truhličky a po dokončení prací vráceny zpět na místo nálezu. Pouze kosti obou stavitelů byly přemístěny jinam - v roce 1929 byly uloženy do dvou malých mramorových sarkofágů při protilehlých stěnách Valdštejnské kaple, nacházejících se na jižní straně katedrály. Na tyto sarkofágy byly poté ještě ke stěně přizděny původní nalezené náhrobní desky (Výroční zpráva 1929,9).

Textilie a další artefakty se do hrobů nevracely. Látky z hrobů obou stavitelů byly vzápětí přiřazeny $\mathrm{k}$ chrámovému pokladu (Podlaha 1930, 107).7 O nálezy z hrobu neznámého jedince zrrejmě nebyl zájem, a tak zůstal v majetku Jednoty pro dostavění Chrámu sv. Víta na Hradě pražském. Možná již někdy na konci 30. let 20. století, spíše však o něco později, byly některé z těchto nálezů předány Ivanu Borkovskému do Archeologického ústavu. Poté byly zřejmě uloženy $\mathrm{v}$ depozitáři, který se $\mathrm{v} 80$. letech přestěhoval do nových prostor ve Vikářské ulici, v nichž pak, zcela zapomenuty, spočívaly až do jejich znovuobjevení v roce 2016.

\section{Inventár̆ hrobu}

V rámci restaurování v roce 2018 bylo rozpoznáno celkem jedenáct textilií - pozůstatků pohřebního oděvu, a fragment kůže - zbytek bot.

Již během předběžného průzkumu se ukazovalo, že inventář hrobu vykazuje rysy pohřbu církevního hodnostáře. Detailní vyhodnocení pak tuto teorii potvrdilo.

\subsection{Lampas s fénixy, pávy a diagonálními úponky}

Zachoval se ve dvou fragmentech (č. 1: $23 \times 34 \mathrm{~cm}$; č. 2: $31,5 \times 19 \mathrm{~cm}$ ). Tkanina je hedvábný lampas. V základu je dutinná tkanina, hlavní osnova provazuje se základním útkem $\mathrm{v}$ atlasové vazbě 4/1 (décochement 2). Pod tím je oddělená vrstva v plátnové vazbě tvořená vaznou osnovou a vzorujícími útky I., II. Ve vzoru jsou dva efekty. Prvním je efekt vzorujícího útku I., který provazuje $\mathrm{s}$ vaznou osnovou v plátnové vazbě. Druhým je efekt vzorujícího zlatého útku II., který provazuje s vaznou osnovou v plátnové vazbě. Pevný okraj se zachoval na jedné straně fragmentu č. 2.

Obdobnou technikou je utkán např́klad lampas italského původu ze 14. století s fénixy mezi vinnými úponky. V základu je atlasová vazba, ve vzoru je plátnová vazba, není ale uvedeno, zda se v základu též jedná o dutinnou tkaninu (Kunstgewerbemuseum, Berlín; Wilckens 1992, 120-121).

\footnotetext{
$7 \mathrm{~V}$ citovaném katalogu se doslova píše, že pod číslem $168 \mathrm{~b}$ jsou ve svatovítském pokladu uloženy ,zbytky látek aj. nalezených $r$. 1928 ve hrobech prvnich stavitelů dómu Svatovitského“. Není jasné, jaké jiné předměty kromě látek měly být v pokladu uloženy. Podle výkopových deníků se mimo textilu našly v hrobě Matyáše z Arrasu „,zbytky lemovani z drátků zelenou patinou pokrytých“ a v hrobě Petra Parléře „malý kousek dřeva, který možná pocházel bud' od úhelnici aneb od lokte". Další osud těchto nálezů není znám; byly-li také uloženy ve svatovítském pokladu, není o tom žádných zpráv.
} 
Ta je jistě na lampasu s mušlemi v šestiúhelnících interpretovaném jako italský z druhé poloviny 14. století. V základu je atlasová vazba 4/1 (décochement 2), ve vzoru je kepr 1/3 S (Abegg-Stiftung, Riggisberg; Otavský-Wardwell 2011, 291-292). Obdobně jako u perského lampasu s úponky, jednorožci a želvami z druhé poloviny 13. století. V základu je atlasová vazba 4/1 (décochement 3), ve vzoru je kepr 1/3 Z (Abegg-Stiftung, Riggisberg; Otavský-Wardwell 2011, 238-241). U všech uvedených lampasů byl vzorující zlatý útek z pozlaceného proužku živočišného podkladu obtočený kolem lněné duše.

Celá látka byla pokryta vzorem vytkaným zlatými a barevnými nitěmi. Na pozadí s paralelně běžícími lehce zvlněnými úponky s malými kvítky rozetového tvaru a dalšími lístky jsou řady vzlétajících pávů a dolů letících fénixů (fenghuangů). Těla ptáků, úponky, rozety a listy jsou vytkány vzorujícím zlatým útkem II. Část listů, rozet a drobné detaily na tělech ptáků jsou tvořeny vzorujícím útkem I. Raport vzoru je v. $20,5 \mathrm{~cm}, \breve{s} .13 \mathrm{~cm}$.

Velmi podobná kompozice se nachází na italském lampasu s nahoru a dolů letícími fénixy z poloviny 14 . století. Úponky jsou více zvlněné, téměř shodné je provedení z nich vycházejících rozet a lístků (Kunstgewerbemuseum, Berlin; Wilckens 1992,120). Shodné prvky jsou také na čínském nebo perském samitu z druhé poloviny 13. století až počátku 14. století, z něhož byla zhotovena část dalmatiky (původně Stralsund; Abegg-Stiftung, Riggisberg; Otavský-Wardwell 2011, 265-273), rovněž se objevují na perské tkanině ze 13. až počátku 14. století s fénixy, pávy a úponky, z níž byla ušita dalmatika Václava IV. (Správa Pražského hradu, Praha; Otavský-Wardwell 2011, 232-234).

Vyhodnocení lampasů s asymetrickým vzorem s prvky ovlivněnými čínskými předlohami se stále vyvijí, dříve se považovaly spíše za italské (Wilckens 1992, 115, Kat. 235; 117, Kat. 240; 118-119, Kat. 242; 120, Kat. 245, 121-122, Kat. 248; Wardwell 1976-1977, 182-187), nověji spíše za předovýchodní (Otavský-Wardwell 2011, 230-232, Kat. Nr. 84, 238-241, Kat. Nr. 88, 261-262, Kat. Nr. 100).

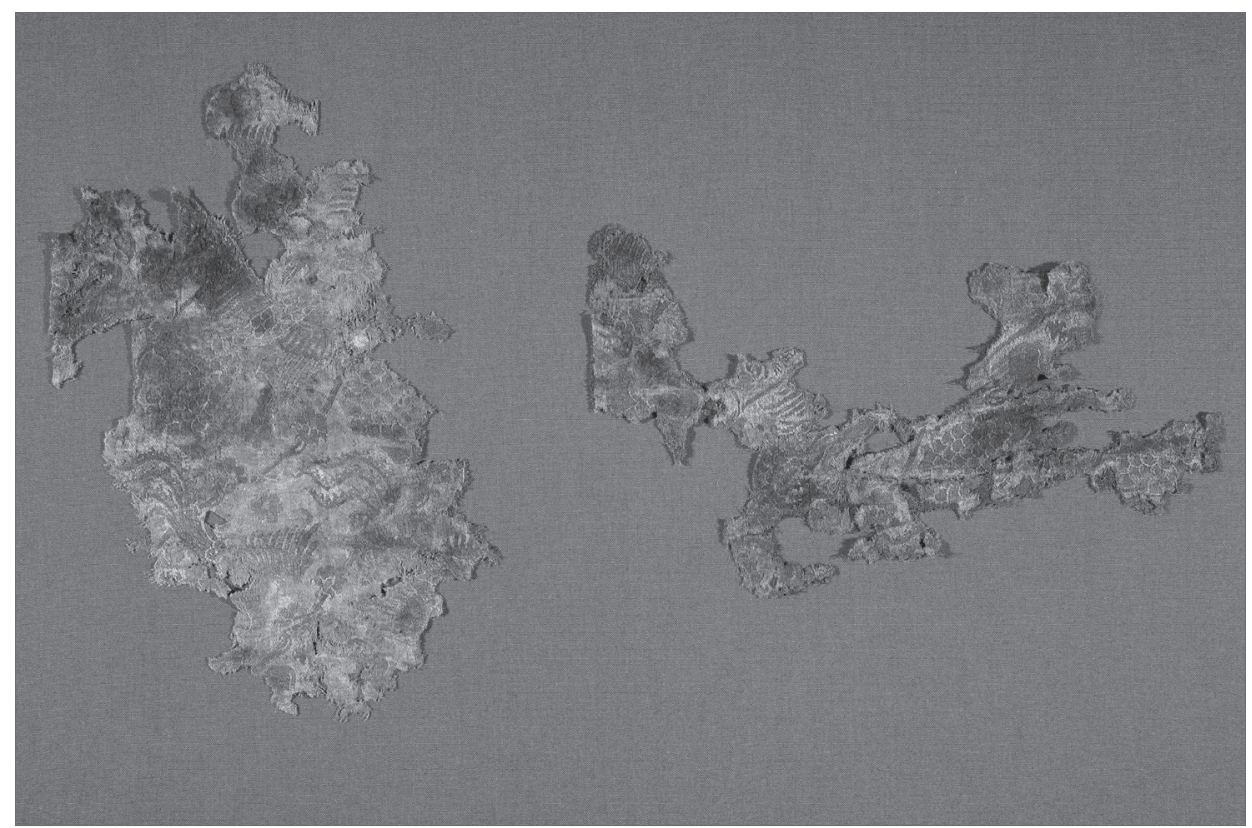

Obr. 1. Lampas s fénixy, pávy a diagonálními úponky. (C) Správa Pražského hradu, foto J. Gloc.

Abb. 1. Lampas mit Phönixen, Pfauen und diagonalen Ranken. (C) Verwaltung der Prager Burg, Foto J. Gloc. 


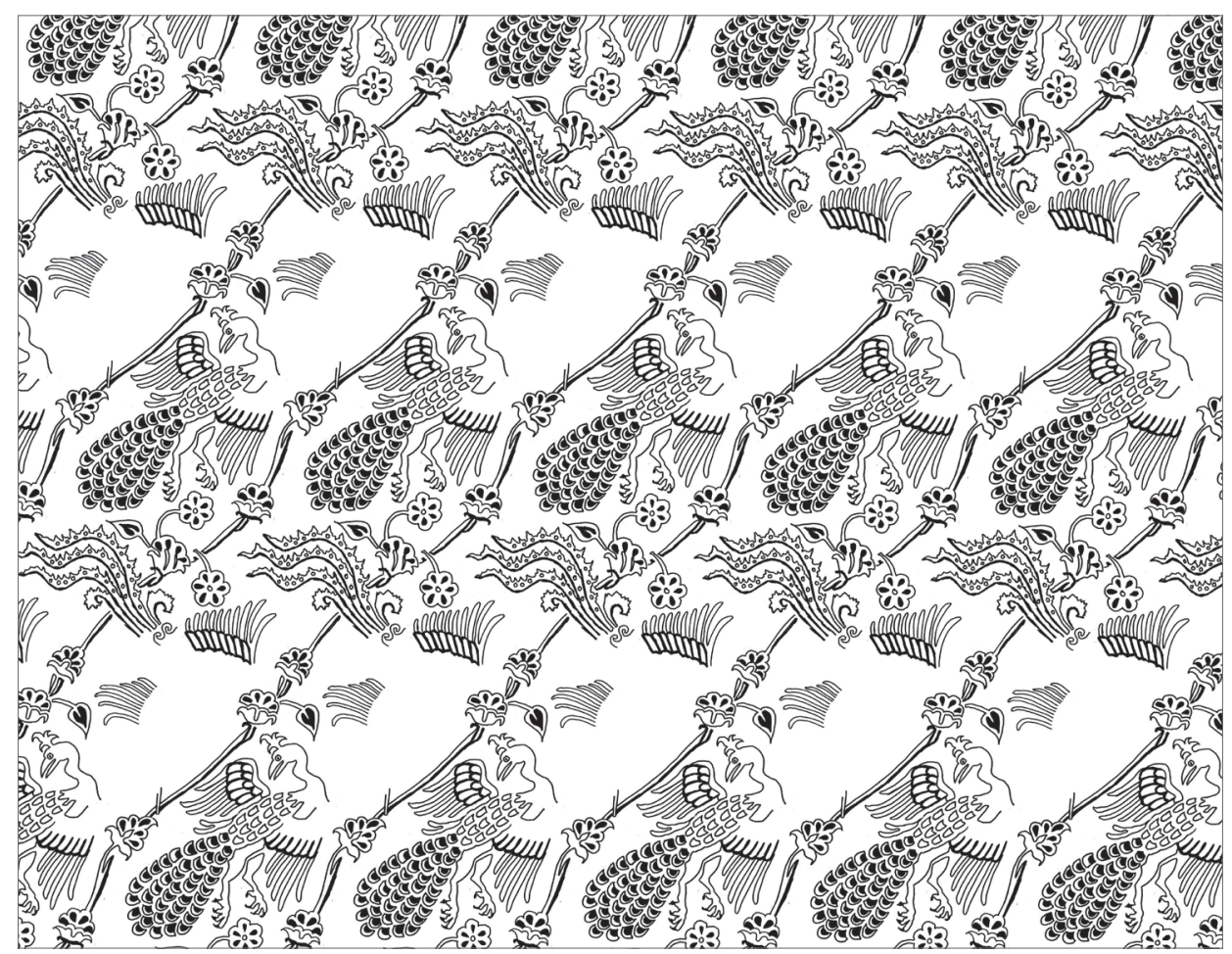

Obr. 2. Rekonstrukce vzoru lampasu s fénixy, pávy a diagonálními úponky. Kresba A. Vrabcová, J. Vlček.

Abb. 2. Rekonstruktion des Lampas-Musters mit Phönixen, Pfauen und diagonalen Ranken. Zeichnung A. Vrabcová, J. Vlček.

Dle nového vyhodnocení lze tkaninu s fénixy, pávy a diagonálními úponky určit jako italskou nebo předovýchodní z období druhé až třetí čtvrtiny 14. století.

Jediným dochovaným krejčovským detailem je na fragmentu č. 1 původní ohyb záložky v délce $8 \mathrm{~cm}$ a šířce $0,5 \mathrm{~cm}$, po její délce se zachovaly dírky po stezích. Původní tvar textilie již nelze zjistit.

Vzhledem k nálezovým okolnostem a k celkovému vyhodnocení souboru, tedy že se jednalo o pohřební výbavu církevního hodnostáře, byla $\mathrm{z}$ látky pravděpodobně ušita kasule.

Původ kasule (ornátu) je ve světském oděvu v antice, postupně se stala svrchním liturgickým mešním rouchem náležejícím pouze kněžím. Tvar kasule byl zprvu kónický, zhruba od 12. století se kvůli snadnější manipulaci začal ornát na bocích zkracovat. $\mathrm{Na}$ přední straně kasule se nacházel svislý pruh, na zadní byl aplikován tzv. dorsální kř́žz, často vidlicového tvaru (Braun 1907, 149-246; Martínek et al. 2008, 293).

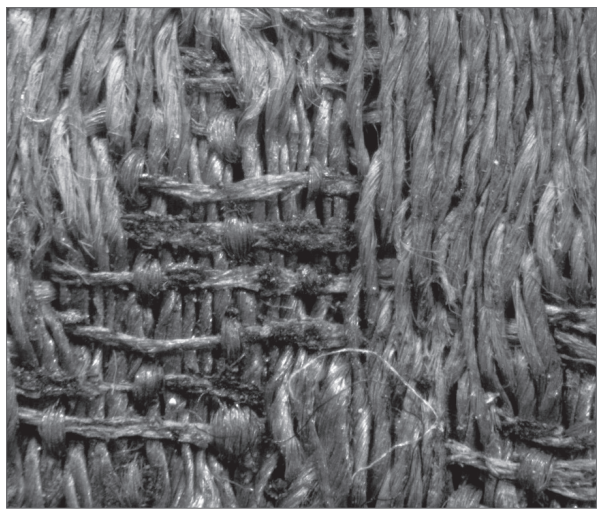

Obr. 3. Snímek lampasu s fénixy, pávy a diagonálními úponky pod mikroskopem. Foto A. Vrabcová, R. Kloudová.

Abb. 3. Aufnahme des Lampas mit Phönixen, Pfauen und diagonalen Ranken unter dem Mikroskop. Foto A. Vrabcová, R. Kloudová. 


\subsection{Nevzorovaný řezaný samet}

Dochoval se ve čtyřech fragmentech (č. 1: v. $18,5 \mathrm{~cm}$, š. $16 \mathrm{~cm}$; č. 2: v. $2 \mathrm{~cm}$, š. $3,3 \mathrm{~cm}$; č. 3 : v. 7,3 cm, š. $9,6 \mathrm{~cm}$; č. 4: v. $10 \mathrm{~cm}, \breve{s} .13,2 \mathrm{~cm})$. Všechny osnovní nitě, a to hlavní i vlasové, provazují se základním útkem v odvozené plátnové vazbě - nepravidelný prř́čný ryps. Tkanina není vzorována, vlas pokrývá celou její plochu.

Analogií k technice je nevzorovaný řezaný samet italského původu, z něhož byl zhotoven svrchní oděv typu houppelande, ve kterém byl do rakve v královské hrobce v katedrále sv. Víta uložen Jan Zhořelecký († 1396; Bravermanová 2006).

Samet lze datovat do druhé poloviny 14. století a byl zhotoven nejspíše v Itálii, př́padně ve Španělsku.

Na fragmentu č. 1 je od horní části směrem zleva doprava ve vlasu vytlačená linie s dírkami po stezích. Vpravo od ní, ve vzdálenosti zhruba $5 \mathrm{~cm}$, je drobný pozůstatek obdobné linie, vlevo od ní, opět ve vzdálenosti $5 \mathrm{~cm}$, je několik dírek a stehů. Vytlačené linie se stejným rozestupem i dírky po stezích se dochovaly též na fragmentu č. 3. U obou fragmentů zůstal mezi liniemi otisk jiné textilie, s níž mohly souviset zachované stopy po šití.

Vzhledem k celkové interpretaci souboru je pravděpodobné, že samet pochází z mitry, tomu odpovídá i vyhodnocení zachovaných krejčovských detailů.

Mitra (infule) měla původně tvar jednoduchého bílého čepce se špičkou, podél spodního okraje býval ozdobný lem (circulus). Okolo roku 1100 se vršek zaoblil a vzápětí nato se ve středu mělce zahloubil, prohlubeň někdy zdobíval prŕčný pásek. Poté se zaoblené výčnělky nad spánky zašpičatěly do dvou rohů (cornua), k dolnímu obvodu se přišívaly dva pruhy visící na záda ( $f a$ nony). Ve 12. století došlo k pootočení mitry a rohy se ocitly nad čelem a temenem. Též ozdobný prríčný pásek se přesunul doprostřed rohů (titulus). Od 14. století se tvar mitry prodlužoval a rozšiřval a okraje špičatých štítů se postupně zaoblovaly. Také se začaly oproti původně bílé používat i barevné tkaniny (Braun 1907, 424-497; Martínek et al. 2008, 297-298).

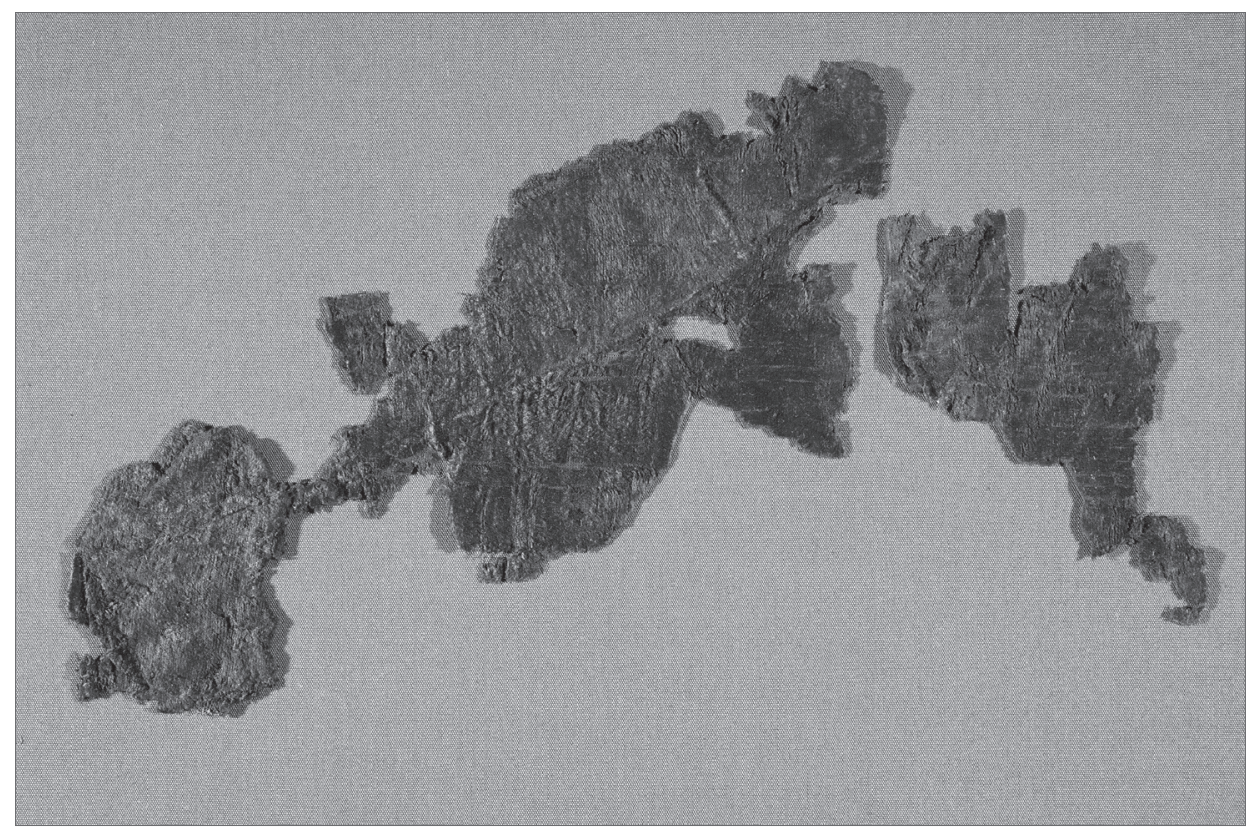

Obr. 4. Nevzorovaný stř́ihaný samet. (C) Správa Pražského hradu, foto J. Gloc.

Abb. 4. Ungemusterter geschnittener Samt. (c) Verwaltung der Prager Burg, Foto J. Gloc. 
Stopy po našití jiné textilie jsou na sametu z hrobu jižně od hrobu Petra Parléře dochovány $\mathrm{v}$ šikmých liniích, což by odpovídalo olemování rohů mitry. Aplikována zde mohla být jedna z tkanic ze stejné pohřební výbavy. Śírkou by nejvíce vyhovovala tkanice č. 7, i její dochovaná délka by dostačovala $\mathrm{k}$ olemování obou rohů. Takováto krejčovská úprava pomocí tkanice se nachází např́íklad na mitře sv. Wolfganga ze začátku 14. století (Diözesanmuseum, Řezno; Blöcher 2012, 307-309). Několik dírek a stehů vlevo od vytlačené linie na fragmentu č. 1 se nachází zhruba uprostřed plochy rohu mitry a může být pozůstatkem po našití tkanice tvořící titulus (případně tkanice č. 9 nebo č. 10) či kovové aplikace. Circulus mitry mohla tvořit další z tkanic ze stejné pohřební výbavy, a to č. 8 , vytkané písmeno $M$ by se potom nacházelo nad čelem. Tkanice č. 9 nebo č. 10 by také mohly pocházet $\mathrm{z}$ fanonů mitry.

Analogií k pravděpodobné hypotéze, že ze sametu byla ušita mitra, je červená sametová mitra sv. Vojtěcha, zdobená perlovou výšivkou a lemováním rohů pomocí úzké tkanice. Datovaná je do první třetiny 14. století, jedná se o bohatě dekorovanou mitru pretiosa (Chrámový poklad u sv. Víta, Pražský hrad; Bravermanová 2012, 43). Takovým typem by tak mohla být i mitra $\mathrm{z}$ hrobu jižně od hrobu Petra Parléře.

\subsection{Nevzorovaná tkanina, tkanice tkaná na \\ destičkách - část rukávu}

Nevzorovaný hedvábný fragment (výška $16,5 \mathrm{~cm}$, šířka $12,5 \mathrm{~cm}$ ) tkaný plátnovou vazbou je spodní částí rukávu. Postranní šev, široký $2 \mathrm{~cm}$, byl sešit hedvábnou nití zapošívacím stehem.

Shodnou nití byla na spodním okraji rukávu také přichycena předním stehem $0,6 \mathrm{~cm}$ široká a $23 \mathrm{~cm}$ dlouhá tkanice zhotovená technikou tkaní na destičkách. Pro její zhotovení bylo použito devět tkacích destiček, v nichž byly navlečeny čtyři osnovní nitě. Hedvábné osnovní nitě byly destičkami vedeny tak, aby výsledný směr stáčení nití v každé jednotlivé destičce byl odlišný, tedy aby docházelo k pravidelnému stř́ídání stáčení osnovních nití ve směru $\mathrm{S}$ a ve směru Z Destičky byly otáčeny stále stejným směrem. Základní lněný útek se téměř nedochoval. Vzorující broché zlatý útek byl v základu veden mezi osnovami a objevoval se pouze na lícové straně tkanice. V místech, kde se otáčel, byl zachycen základním útkem. Jednoduchý geometrický vzor tvoří průběžně pod sebou umístěné zašpičatělé ovály.

Tkanina rukávu nevykazuje žádné znaky, podle nichž by bylo možné ji přesněji datovat či určit provenienci. Lze pouze konstatovat, že byla v průběhu středověku vyrobena v některé z hedvábnických oblastí v Asii či jižní Evropě.

Geometrický motiv vytkaný vzorujícím broché zlatým útkem je např́íklad na tkanici č. 83 zhotovené na devíti destičkách, která je datována do přelomu 13. a 14. století a pochází z Německa (Church Onze-Lieve-Vrouw Hemelvaart, Sint Truiden; Spies 2000, 210-211). Na 
Pražském hradě tkanice s přidaným zlatým vzorujícím útkem pochází ze společné rakve královen, je datovaná do 14. století a byla zhotovena v západní, př́ípadně stř̌ední Evropě (Správa Pražského hradu, Praha; Bravermanová-Březinová 2014). Také je součástí dalmatiky z látky s úponky, fénixy a pávy, je též datovaná do 14. století a byla zhotovena v západní, př́padně střední Evropě (Správa Pražského hradu, Praha; Odstrčilová 2020). Materiálové složení kovového útku se u těchto dvou tkanic od tkanice z hrobu jižně od hrobu Petra Parléře odlišuje, navíc útky jsou lancé, a nikoli broché.

Tkanici z hrobu jižně od hrobu Petra Parléře je možno považovat za výrobek ze 14. století zhotovený v západní, případně střední Evropě.

Vzhledem k jemnému materiálu a tvaru zužujícímu se směrem k zápěstí pochází ćást rukávu zřejmě ze základního oděvu. V prŕípadě církevního roucha přichází do úvahy alba.

Alba je základním církevním oděvem určeným všem duchovním. Vznikla z antické tuniky, byla nařasená a měla přiléhavé rukávy. U spodního okraje a na dolní části rukávů byla často zdobená parurami (aplikovaná textilie obdélného či čtvercového tvaru bud' vyšívaná, nebo zhotovená z odlišné luxusní tkaniny), ve středověku byly parury též vyšívané zlatou nití (alba aurifrisiata). Alba měla charakteristickou bílou barvou a nejčastěji se šila z lněného plátna (Braun 1907, 57-101; Martínek et al. 2008, 290), ve středověku se však vyskytovaly, i když nikoli tak často, též alby hedvábné. Dosvědčují to chrámové inventáře (k tomu Braun 1907, 80), v inventáři chrámového

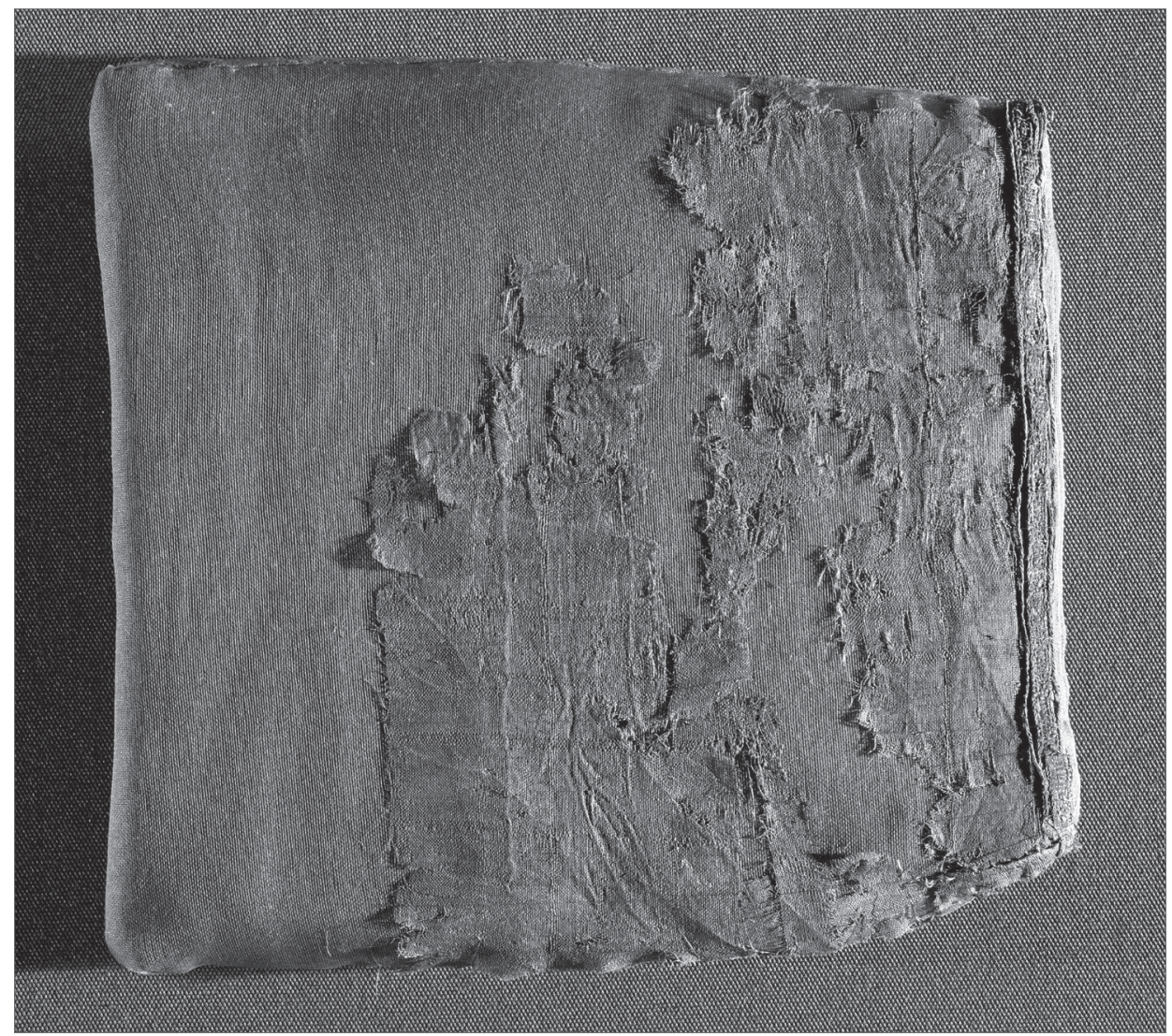

Obr. 6. Fragment rukávu po restaurování. @ Správa Pražského hradu, foto J. Gloc.

Abb. 6. Ärmelfragment nach Restaurierung. (C) Verwaltung der Prager Burg, Foto J. Gloc. 
pokladu u sv. Víta z roku 1387 se např́íklad hovoří o albě z tenkého hedvábí - „(...) alba de tenui serico (...)“ (Podlaha-Šittler 1903, zápis č. 274), z roku 1441 o dvou hedvábných albách „(...) duae albae sericae (...)“ (Podlaha-Šittler 1903, zápis č. 48).

Pokud tedy část rukávu pochází z alby, je to výjimečný doklad tohoto typu církevního oděvu ušitého z hedvábné tkaniny. Jako př́klady shodně řešených spodních okrajů rukávů s našitými tkanicemi zhotovenými na destičkách lze uvést alby arcibiskupů Gilona I. Cornuta († 1254) a Pierra de Charny († 1274; obojí Cathédrale Saint-Étienne, Sens; Spies 2000, 234-235).

$\mathrm{V}$ př́ípadě alby z hrobu jižně od hrobu Petra Parléře by parurou či parurami mohla být alespoň jedna nebo obě výšivky ze stejné pohřební výbavy (č. 5, č. 6).

\subsection{Nevzorovaná tkanina-punčocha}

Dva fragmenty (č. 1: výška 28,5 cm, šířka $25 \mathrm{~cm}$; č. 2: výška 16,5 cm, šířka 13,5 cm) hedvábné tkaniny tkané plátnovou vazbou jsou dosud sešity tak, že tvoří tvar punčochy. Fragment č. 1 je jen částí dílu původně pokrývající holeň a patu, lýtková partie a šev vzadu zachovány nejsou. Vykrojení na nártu vybíhá do malé špičky. Fragment č. 2 pochází z dílu nacházejícího se na nártové části, špička se nedochovala. Oba díly jsou na nártu spojeny hřbetovým švem s částečně zachovaným předním stehem hedvábnou nití. Záložky obou dílů jsou na rubu společně přehnuty ke straně jednoho z dílů a vše je dohromady prošito shodnou nití předním stehem. Původní délka punčochy a šířka přes lýtko není známa.

Tkanina punčochy nevykazuje žádné znaky, podle nichž by bylo možné ji přesněji datovat či určit provenienci. Lze pouze konstatovat, že byla v průběhu středověku vyrobena v některé z hedvábnických oblastí v Asii či jižní Evropě.

Pontifikální punčochy spolu s pontifikálními střevíci tvořilo církevní odění nohou již od 6. století, od 8. století právo je užívat ponejvíce přináleželo biskupům a opatům, kteří jej získávali zvláštním privilegiem. Biskup navíc jako nositel evangelia musel být schopen se rychle dostavit tam, kde bylo potřeba šiřit a upevňovat křestanství, proto mělo liturgické odění nohou zvláštní význam. Punčochy také byly ztotožňovány se symbolem boží ochrany. Zhruba od 10. století se kromě lnu vyráběly i z hedvábí (Braun 1907, 384-424; Martínek et al. 2008, 298).

Nejbližší analogií k punčoše z hrobu jižně od hrobu Petra Parléře je hedvábná punčocha z tkaniny s plátnovou vazbou nalezená rovněž roku 1928 v hrobě biskupa Mikuláše $(† 1258)$ v katedrále sv. Víta (Chrámový poklad u sv. Víta, Pražský hrad; Bravermanová 2007, 479-480). Pozůstatky punčoch byly také nalezeny v hrobě biskupa Bernarda († 1240) v katedrále sv. Víta, byly zhotoveny z hedvábného vzorovaného lampasu (Chrámový poklad u sv. Víta, Pražský hrad; Bravermanová-Foltýn-Sliwka 2010,12). Ze 14. století pocházejí např́ílad pontifikální punčochy zhotovené z pruhované hedvábné látky (Dom St. Stephanus und St. Sixtus, Halberstadt; Braun 1907, 411). Všechny výše uvedené prríklady se vztahují k církevním činitelům.

Nález takovéto punčochy v hrobě jižně od hrobu Petra Parléře významně svědčí ve prospěch hypotézy, že hrob náležel vysoce postavené církevní osobě.

\subsection{Výšivka s motivem žaludi̊, dubových a hlohových listi̊}

Dochovala se v šesti fragmentech (č. 1: v. 16 cm, š. 26,3 cm; č. 2: v. 8,5 cm, š. 14 cm; č. 3: v. 12 cm, š. $7 \mathrm{~cm}$; č. 4: v. 10,5 cm, š. 15,5 cm; č. 5: v. $6,5 \mathrm{~cm}$, š. $8,5 \mathrm{~cm}$; č. $6:$ v. $3 \mathrm{~cm}, \breve{s}$. $7,5 \mathrm{~cm}$ ). Výšivka byla zhotovena technikou kladené nitě na svrchní a podkladové tkanině.

\subsection{Výšivka s motivem vinných listů}

Dochovala se ve čtyřech fragmentech (̌̌. 1: v. $21 \mathrm{~cm}, \breve{s} .19,5 \mathrm{~cm}$; č. 2: v. 14,5 cm, š. $11 \mathrm{~cm}$; č. 3 : v. $7,8 \mathrm{~cm}, \breve{s} .13,5 \mathrm{~cm}$; č. 4: v. $4 \mathrm{~cm}, \breve{s} .4,2 \mathrm{~cm}$ ). Výšivka byla zhotovena technikou kladené nitě na svrchní a podkladové tkanině. 


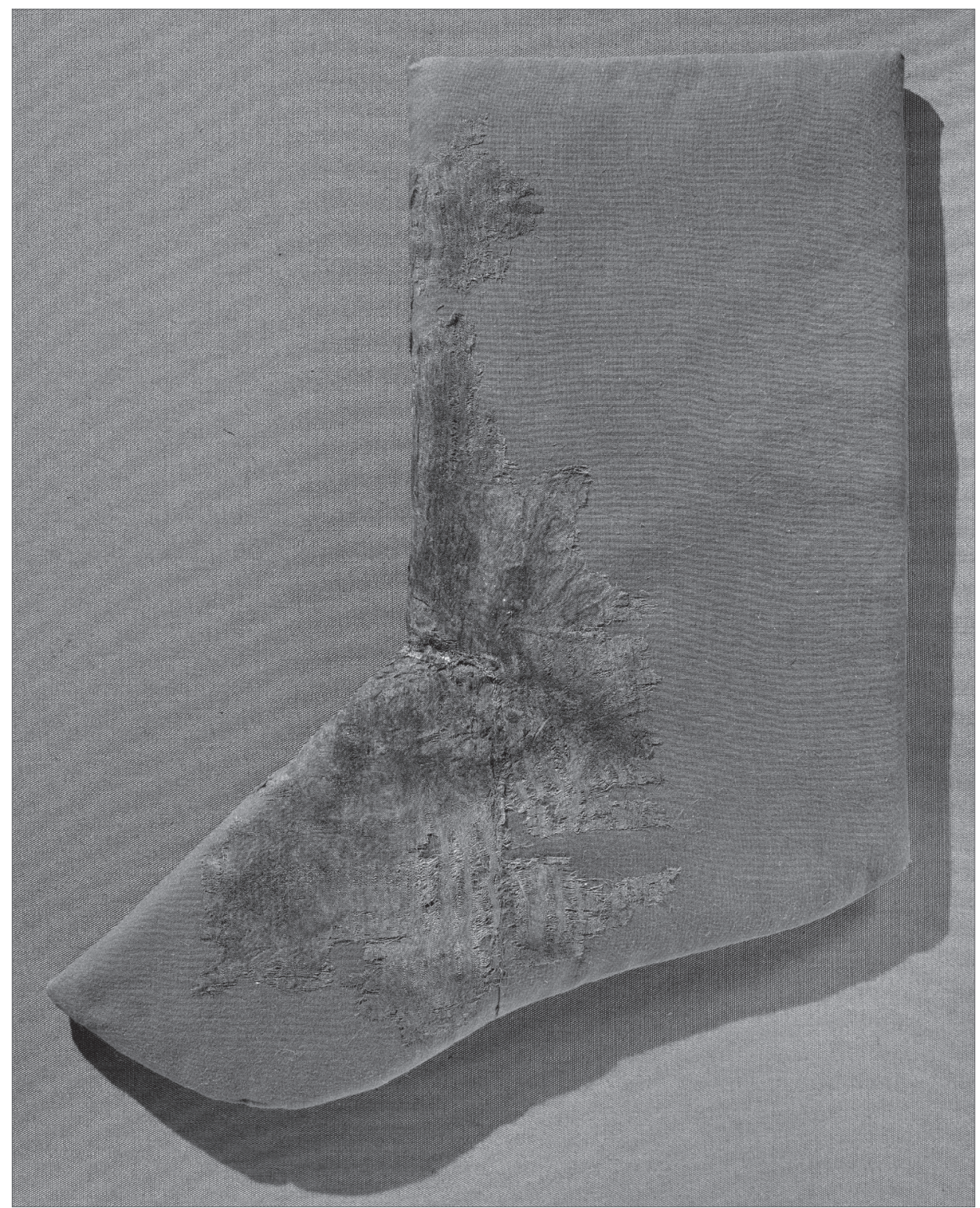

Obr. 7. Fragment punčochy po restaurování. () Správa Pražského hradu, foto J. Gloc.

Abb. 7. Strumpffragment nach Restaurierung. (C) Verwaltung der Prager Burg, Foto J. Gloc.

Obě výšivky $(\check{c} .5,6)$ byly zhotoveny z jemné hedvábné tkaniny tkané plátnovou vazbou podložené na rubu lněnou tkaninou v plátnové vazbě. Podkladová tkanina se zachovala hůře. Vyšívací nitě I. a II. ležící na líci svrchní tkaniny byly zachyceny sérií drobných stehů jdoucích zespodu skrz obě tkaniny.

První výšivka (č. 5) měla pravoúhlé středové pole, které bylo rozděleno do sítě čtverců o velikosti 8,5-9 cm. V každém čtverci jsou čtyřri shodně orientované lunety vějírovitého tvaru, vždy dvě a dvě pod sebou. Lunety vyplňuje stylizovaný lístek připomínající hloh. Středové pole 


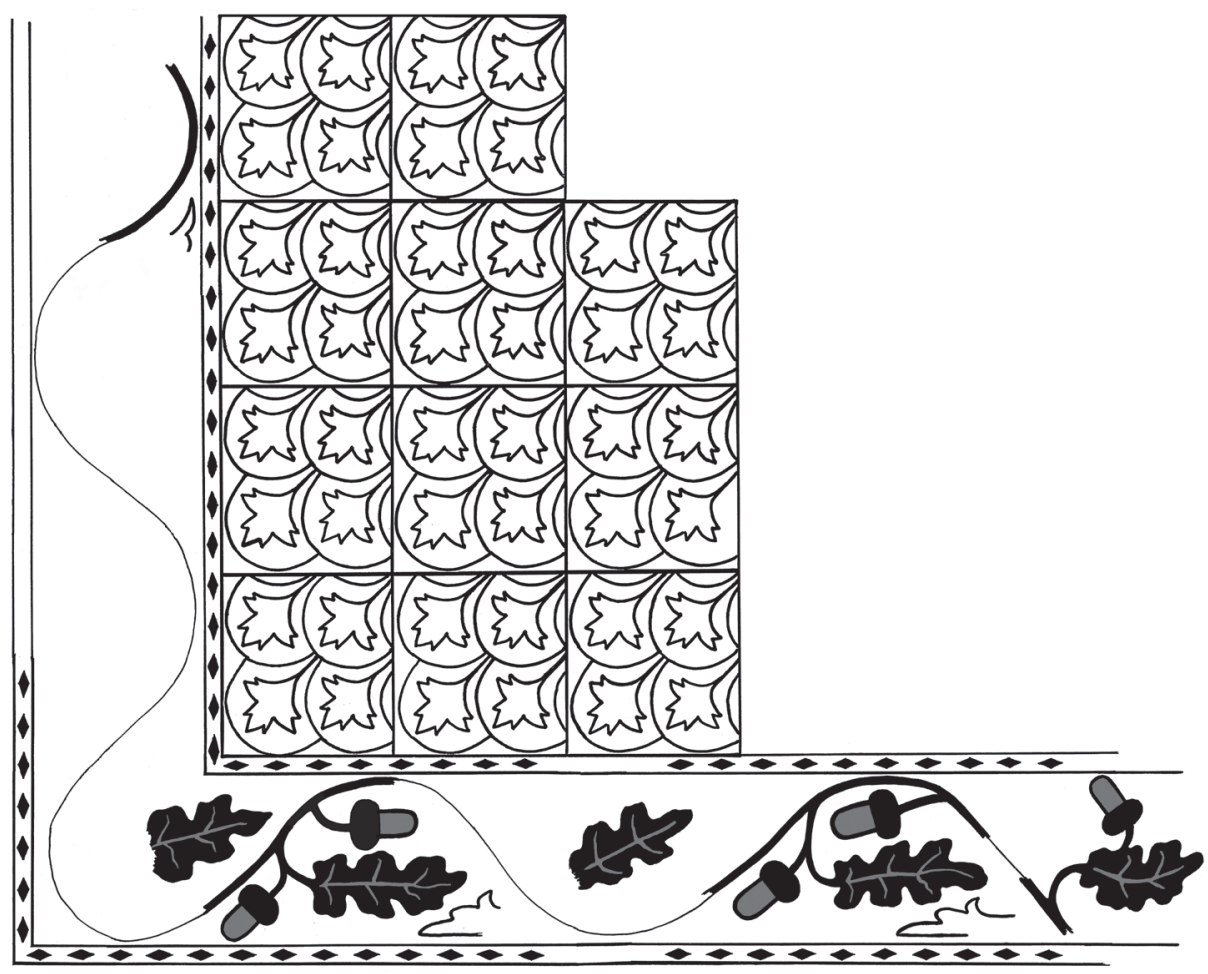

Obr. 8. Rekonstrukce vzoru výšivky s motivem žaludů, dubových a hlohových listů. Plochy vyšité zlatými nitěmi znázorněny černě, plochy vyšité barevnými nitěmi znázorněny šedě. Kresba A. Vrabcová, J. Vlček.

Abb. 8. Rekonstruktion des Stickmusters mit dem Motiv von Eicheln, Eichen- und Weißdornblättern. Mit goldenem Stickgarn gestickte Flächen sind schwarz dargestellt, mit buntem Stickgarn gestickte Flächen sind grau dargestellt. Zeichnung A. Vrabcová, J. Vlček.

je po okrajích lemováno $10,5 \mathrm{~cm}$ širokou bordurou. Její střed tvoří pás široký $8,5 \mathrm{~cm}$ a probíhá v něm úponek, z něhož vyrůstají dubové listy a žaludy. Tento motiv je po obou stranách lemován užšími pásky o šířce asi $1 \mathrm{~cm}$ s drobnými kosočtverci mezi dvěma liniemi. Všechny motivy jsou provedeny zlatou vyšívací nití I., pouze žilnatina listů a vlastní žaludy vyšívací nití II. Detaily výšivky se nepodařilo rekonstruovat, stejně jako původní rozměry.

U druhé výšivky (č. 6) se zachovala jenom okrajová bordura pravoúhlého tvaru, středové pole chybí. Z úponku vyrážejí listy vinné révy, tyto prvky mají zlatou nití vyšitou pouze obrysovou linku. Po obou stranách je drobnější úponek se stylizovanými lístky. Původní rozměry výšivky se nepodařilo zjistit.

Práce s tzv. kladenou nití je jednou z nejstarších vyšívačských technik. Pokud se zdobila menší plocha, používaly se dva druhy nití. Svrchní strana látky se pokryla požadovanou délkou stehů, které byly potom zespodu přichyceny druhou sérií drobných stehů, viditelných i na líci. Pro vyšití velkých ploch se mohlo pracovat i se třemi nitěmi. Jedna z prvních prací s tzv. kladenou nití se nachází na výšivce z Bayeux z let 1066-1077 (Bayeux, Musée de la reine Mathilde), v období vrcholného středověku se využívala čím dál tím hojněji. Nit sestávající z pozlacené stříbrné lamely obtočené kolem duše byla nejčastějším materiálem pro výšivku, zlatý vzor tím vynik1 (Schuette-Müller-Christensen 1964, VIII, XI). Vzhledem k širokému použití tohoto způsobu výšivky nelze z něj vyvodit podporu pro přesnější datování či provenienci. 


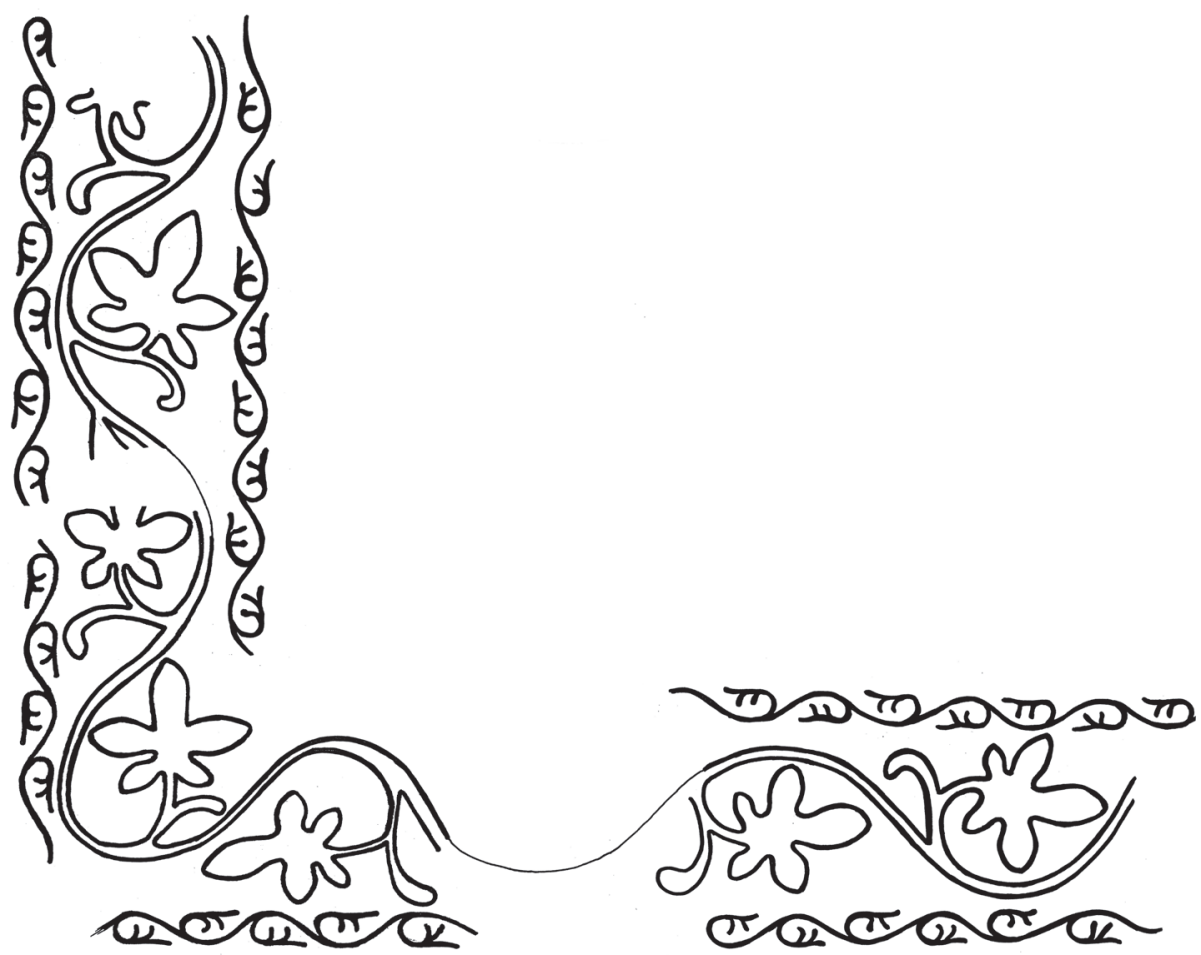

Obr. 9. Rekonstrukce vzoru výšivky s motivem vinných listů. Kresba A. Vrabcová, J. Vlček.

Abb. 9. Rekonstruktion des Stickmusters mit Weinrebenblättermotiv. Zeichnung A. Vrabcová, J. Vlček.

Shodný materiál a technika jako se nachází na výšivkách z hrobu jižně od hrobu Petra Parléře je na hedvábné tkanině v plátnové vazbě, na níž je vyšívaná bordura s motivem úponků a lilií, provedená kladenou nití zhotovenou z pozlacené stříbrné lamely s duší. Dochovaný fragment je považován za francouzskou práci ze začátku 15. století (Musée de Cluny, Paříž; inv. č. 3364).

Výtvarné analogie k jednotlivým výzdobným motivům lze nalézt i u českých stř̌edověkých prací. Zlatou nití je vyšita např́íklad lněná parura dalmatiky s námětem Smrt Panny Marie. Okolo hlavního výjevu je bordura s úponkem, z něhož vybíhají rozety. Výšivka je datována do období 1320-1330 a pochází zřejmě z Čech (Germanisches Nationalmuseum, Norimberk; Wilckens 1991, 252-253). Okrajová bordura s dubovými lístky se nachází na perličkami vyšívaných parurách dalmatiky s polofigurami Krista a Panny Marie, světci a světicemi datovaných do poslední třetiny 14. století až první třetiny 15. století. Výšivka byla zřejmě zhotovena v Čechách (Chrámový poklad u sv. Víta, Pražský hrad; Bravermanová 2012, 108). Výtvarně obdobná bordura je také na závěsu se scénami ze života sv. Mikuláše, výšivka barevnými hedvábnými nitěmi na lněné tkanině pochází z Dolního Saska z druhé poloviny 14. století (Kunstgewerbermuseum, Berlín; Schuette-Müller-Christensen 1964, 308). Bordura s úponkem, z něhož vycházejí listy vinné révy, se zase nachází na antependiu z Pirny považovaném za českou práci ze 40. let 14. století. Výšivka je provedena zlatými a barevnými hedvábnými nitěmi (Staatliche Kunstsammlungen, Kunstgewerbemuseum, Drážd’any; Schuette-Müller-Christensen 1964, 312).

Podle výše uvedených technických i vzorových analogií lze obě fragmentárně dochované výšivky z hrobu jižně od hrobu Petra Parlére považovat snad za českou práci z druhé poloviny 
14. století. V té době dosahovala česká výšivka mimořádně vysoké kvality (Wetter 2001). Anebo se jedná o import ze západní Evropy.

Podle shodných materiálů použitých na svrchní i podkladovou tkaninu a podle techniky výšivky se lze domnívat, že obě textilie původně pravoúhlého tvaru mohly mít obdobnou funkci. Pokud byly pozůstatkem církevního oděvu, zřejmě se jednalo o parury, ${ }^{8}$ obdélné zdobné aplikace na dalmatikách, tunicellách či albách, nacházející se od středověku na těchto paramentech (Martínek a kol. 2008, 290-292). Nejčastěji byly bohatě vyšívané zlatými a různobarevnými hedvábnými nitěmi, mohly však být i ze vzácných tkanin, lišících se od podkladové látky oděvu. $\mathrm{K}$ českému prostředí se $\mathrm{z}$ období vrcholného středověku váží parury dalmatiky se zákonními polofigurami a rožmberským znakem, nyní sešité v tzv. Třeboňské antependitum (Národní muzeum, Praha; Zeminová 1974, 127-128), výše zmíněné parury dalmatiky s polofigurami Krista a Panny Marie, světci a světicemi či vyšívané parury dalmatik s legendou o sv. Vigiliovi (Museo Diocesano Tridentino, Trident; Wetter 2006, 444-446).

Parury se nacházejí i na albách. Na dvou středověkých lněných albách je např́klad doložena jak parura zhotovená ze vzorované látky datované do 13.-14. století (Muzeum Schnütchen, Köln; Sporbeck 2001, 63-65), tak vyšívaná, která je považována za práci sv. Kláry (Santa Chiara, Assisi; Braun 1907, 83).

Parury na albách mají spíše čtvercový tvar než obdélný (Zeminová 1974, 130-131), původní tvar obou výšivek z hrobu jižně od hrobu Petra Parléře se však nepodařilo rekonstruovat. Pokud byly parurami, mohly být původně aplikovány na albě, z níž se dochoval rukáv s manžetou (textilie č. 3). Vzhledem k převažující výšivce zlatou nití by se tak jednalo o tzv. albu aurifrisiata.

Alespoň jedna z výšivek však mohla být i svrchní částí polštáře (např. povlak polštáře z první poloviny 12. století; Soest, St Patroklus; Schuette-Müller-Christensen 1964, 299, kat. č. 39).

\subsection{Tkanice s mandorlami a kosočtverci}

Dochovala se v šířce $5 \mathrm{~cm}$ ve čtyřech na sebe navazujících fragmentech (délka - č. 1: $33,3 \mathrm{~cm}$; č. 2: $5,8 \mathrm{~cm}$; č. 3: 9,3 cm; č. 4: 19,8 cm), původní délka tedy byla minimálně $68 \mathrm{~cm}$. Tkanice byla utkána technikou samitum, kdy nitě hlavní lněné osnovy leží mezi vrstvami útků a vazná hedvábná osnova provazuje s útky I. a III. shodně v keprové vazbě $1 / 4 \mathrm{Z}$. Pozadí vzoru tvoří lancé zlatý útek I. a vzor broché zlatý útek II. Ten s vaznou osnovou neprovazuje, ale na líci tvoří flotáže podle potřeb vzoru. Lněný lancé útek III. zůstává na rubu, otáčí se ve vzdálenosti $0,1-0,15 \mathrm{~cm}$ od kraje a přitom zachytává útek I. Ten je na kraji mírně vytažen a přetočen na rub, po zachycení útkem III. se vrací na líc.

Vzor tvořený broché zlatým útkem II. sestává ze dvou navzájem se kř́ižících vlnovek, které vytvářejí řady mandorl a drobných kosočtverců. V každé mandorle je plamínkovitý útvar. Ze dvou vrcholů každého kosočtverce, které jsou obráceny k okrajům tkanice, vybíhají na opačné strany dva žaludy, jejichž stonky jsou na tkanici vyšity hedvábnou nití.

\subsection{Tkanice s kosočtverci a písmenem}

Dochovala se v šířce $6 \mathrm{~cm}$ ve dvou fragmentech (délka - č. 1: 11,7 cm; č. 2: 7,5 cm). Tkanice byla utkána technikou samitum, kdy nitě hlavní lněné osnovy leží mezi vrstvami útků a vazná hedvábná osnova provazuje útky par passée v odvozené keprové vazbě - odvozený útkový křížový kepr 1/7/1/5/1/3. Vzor tvoří lancé zlatý útek I. a broché hedvábné útky II. a III. Lněný lancé útek IV. zůstává na rubu, otáčí se ve vzdálenosti $0,1-0,15 \mathrm{~cm}$ od kraje a přitom zachytává útek I. Ten je na kraji mírně vytažen a přetočen na rub, po zachycení útkem III. se vrací na líc.

Vzor tvořený lancé kovovým útkem I. vytváří v celé ploše sít' kosočtverců. Na fragmentu č. 1 se dále dochovaly pozůstatky ornamentu vytvořeného broché hedvábnými útky, kdy útek II.

8 Také se užíval název pretext znamenající obecně ozdoby kostelních textilií (Zeminová 1974, 127-128). 


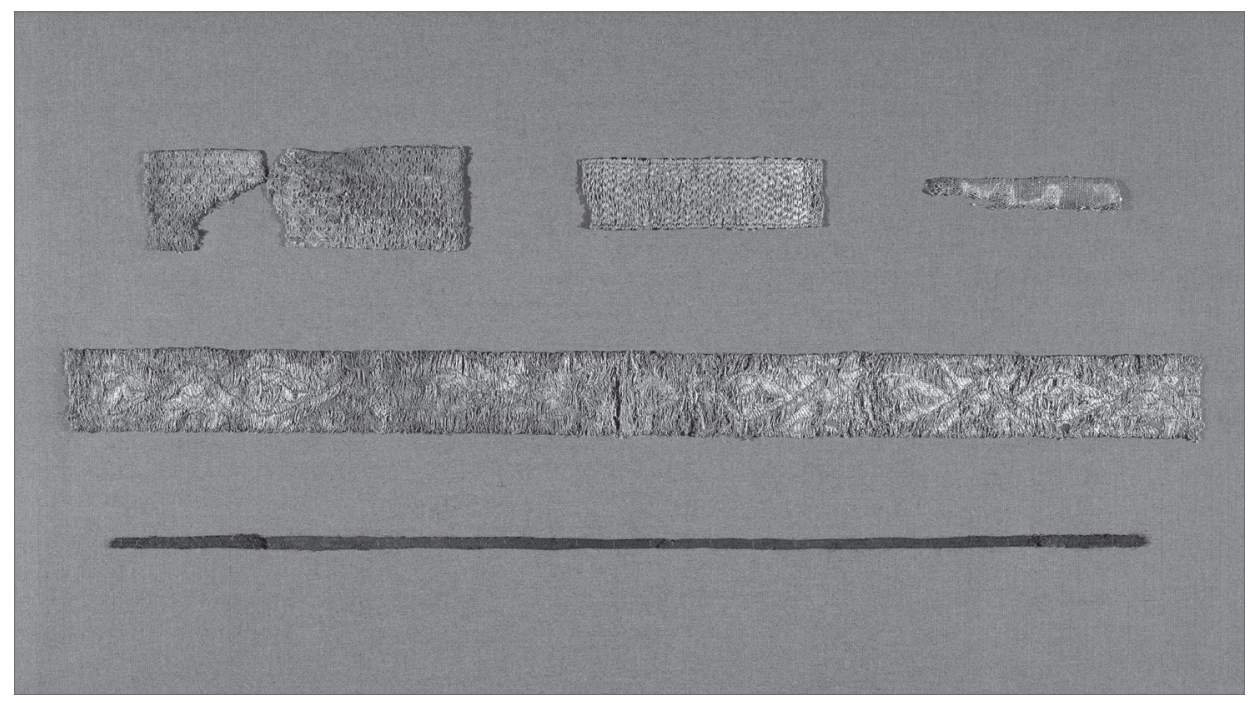

Obr. 10. Tkanice a šňůrka po restaurování. @ Správa Pražského hradu, foto J. Gloc.

Abb. 10. Band und Schnur nach Restaurierung. (C) Verwaltung der Prager Burg, Foto J. Gloc.

světlejší barvy tvoří plochu motivu a útek III. tmavší barvy jej lemuje. Motivem mohlo být majuskulní gotické písmeno M. Na fragmentu č. 2 se broché útky II. a III. zachovaly velmi fragmentárně.

Na okraji fragmentu č. 1 je po šířce záložka 1,3 cm zajištěná stehy šicí nití I. Na rubu, v místě, kde je motiv vytvořený útkem II., je dále asi $2 \mathrm{~cm}$ dlouhý steh šicí nití II.

\subsection{Tkanice s lomenými liniemi}

Dochovala se $\mathrm{v}$ jednom fragmentu (délka $14,4 \mathrm{~cm}$ ) o šířce $4,2 \mathrm{~cm}$. Tkanice byla utkána technikou samitum, kdy nitě hlavní lněné osnovy leží mezi vrstvami útků a vazná hed-

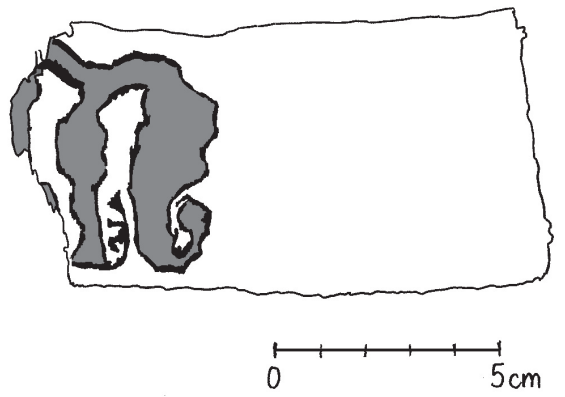

Obr. 11. Zakreslení písmene na tkanici s kosočtverci. Kresba A. Vrabcová, J. Vlček.

Abb. 11. Einzeichnung des Buchstabens auf dem Band mit Rauten. Zeichnung A. Vrabcová, J. Vlček. vábná osnova váže útky par passée v odvozené keprové vazbě - útkový křížový kepr 1/7. Vzor tvoří lancé zlatý útek I. Lněný lancé útek II. je na rubu, otáčí se ve vzdálenosti $0,2 \mathrm{~cm}$ od kraje a přitom zachytává útek I. Ten je na kraji mírně vytažen a přetočen na rub, po zachycení útkem II. se vrací na líc.

Vzor tvořený lancé kovovým útkem I. vytváří v celé ploše sít' lomených linií.

Všechny tři tkanice vykazují shodné technické parametry - jsou utkány technikou samitum, mají lněné hlavní osnovy a jeden z útků je lněný. Dále vždy jeden z dalších útků je lancé a z pozlacené kovové lamely s hedvábnou duší. U dvou tkanic jsou navíc i broché útky (č. 7 z pozlacené kovové lamely, č. 8 dva hedvábné). Funkce lněného útku je kromě vazební konstrukce i zachycení zlatého lancé útku na rubu.

Tyto parametry odpovídají charakteristice tkanic zhotovených v Kolíně nad Rýnem v období od konce 13. do 15. století. U tzv. kolínských tkanic se jako kovový útek vesměs používal 


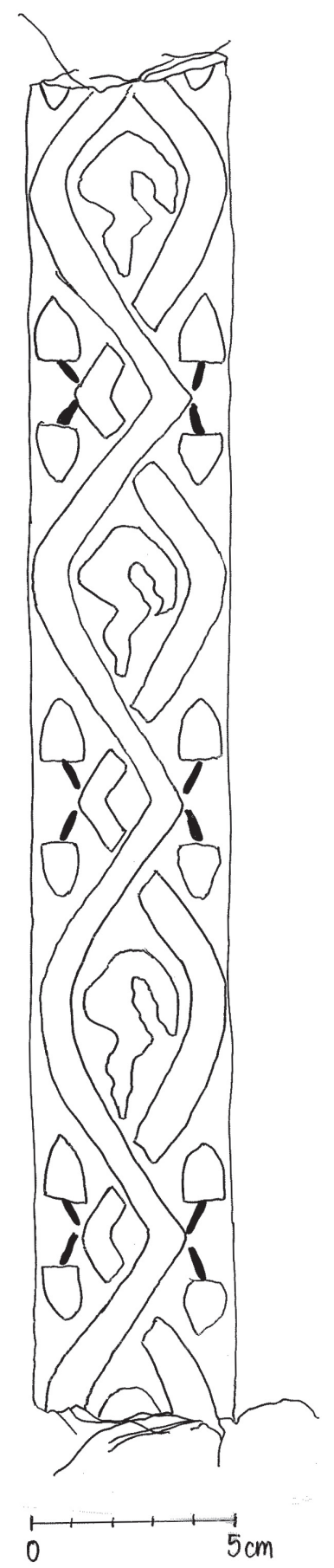

Obr. 12. Zakreslení vzoru na tkanici s mandorlami a kosočtverci. Kresba A. Vrabcová.

Abb. 12. Einzeichnung des Musters auf dem Band mit Mandorlen und Rauten. Zeichnung A. Vrabcová. proužek pozlaceného živočišného podkladu obtočený okolo lněné duše, který vytvářel pozadí bohatých vzorů vytkaných barevnými hedvábnými útky. Méně často se používala i plochá pozlacená lamela obtočená kolem duše. Tkanice často zdobily vytkávané nebo vyšívané jednoduché mariánské, christologické a další biblické motivy a nápisy (Sporbeck 2001, 38-39; Wetter 2012, 316-321).

Blízkými analogiemi ke tkanicím, včetně použití pozlacené kovové lamely obtočené kolem hedvábné duše, je například tkanice s celozlatým geometrickým vzorem, která byla druhotně připevněna na tzv. Bamberské antependium. Je datována do 14.-15. století a byla zhotovena v Německu (Bayeriches Nationalmuseum, Mnichov; Durian-Ress 1986, 100-101). Též tkanice s ptáky a geometrickým ornamentem je určena jako kolínská z 13.-14. století (Kunstgewerbemuseum, Berlin; Wilckens 1992, 128).

$\mathrm{V}$ př́ípadě tkanic z hrobu jižně od hrobu Petra Parléře se jednalo o téměř celozlaté tkanice, hedvábné útky se nacházejí jenom na tkanici č. 8, kde vytkávaly zřejmě písmeno M (Marie?).

Tkanice č. 7, 8 a 9 je tedy možno datovat do období vrcholného středověku a pocházejí zřejmě z některé dílny v Kolíně nad Rýnem, př́ípadně jinde $\mathrm{v}$ Německu. Původně byly našity na některém z oděvů nalezeném $\mathrm{v}$ hrobě jižně od hrobu Petra Parléře, nejpravděpodobnější je mitra, kde mohly tvořit olemování rohů (tkanice č. 7), circulus (tkanice č. 8), titulus či jeden z fanonů (tkanice č. 9).

\subsection{Tkanice}

Dochovala se v šiřrce $1,9 \mathrm{~cm}$ (původní šíře není známa) v jednom fragmentu (délka $11 \mathrm{~cm}$ ). Tkanice je utkaná odvozenou plátnovou vazbou - pravidelný podélný ryps. Osnova i útek jsou z kovové nitě.

Zachoval se jeden pevný okraj, v místě druhého jsou rozvolněné nitě. $\mathrm{Na}$ jednom konci je $\mathrm{v}$ délce $1 \mathrm{~cm}$ záložka.

Analogií je tkanice tkaná plátnovou vazbou, jejíz osnovy i útky jsou zhotovené ze shodné zlaté nitě. Je datovaná do období vrcholného středověku a pochází ze smetištní vrstvy z centra Prahy (Národní památkový 
ústav, Praha; Bravermanová-Březinová 2016, 139-143). Rovněž tkanice č. I., která lemuje křŕž na kasuli C3 z 15. století (Der Dom St. Peter und Paul, Brandenburg; Jehle-Wetter 2005, 238-239).

Nevzorovaná tkanice nevykazuje žádné znaky, podle nichž by bylo možné ji přesněji datovat či určit provenienci. Lze však předpokládat, že byla v průběhu středověku vyrobena v některé $\mathrm{z}$ textilních dílen $\mathrm{v}$ Evropě, včetně českých zemí - v tom př́ípadě byl použit importovaný materiál.

Vzhledem $\mathrm{k}$ nálezovým okolnostem se může jednat o zbytek církevního roucha osoby pohřbené v hrobě jižně od hrobu Petra Parléře. Tkanice tak mohla být našita na některém z jeho oděvů. Nejpravděpodobnější je sametová mitra, na níž mohla tvořit titulus nebo fanon.

\subsection{1 Šn̆ưrka}

Dochovala se v šiřce $0,4-0,8 \mathrm{~cm}$ ve čtyřech fragmentech (délka - č. 1: 9,5 cm; č. 2: 23,5 cm; č. 3: $22,8 \mathrm{~cm}$; č. 4: $6,5 \mathrm{~cm})$, její původní délka tedy byla nejméně $62,3 \mathrm{~cm}$. Je zhotovená technikou smyčkového prstového splétání z deseti smyček, skládajících se vždy ze čtyř nití. Na šňủrce jsou zbytky šicích nití.

Analogií $\mathrm{k}$ technice jsou dvě šňůrky zhotovené technikou smyčkového prstového splétání z pěti smyček pocházející z pohřební výbavy biskupa Bernarda $\mathrm{z}$ katedrály sv. Víta († 1240). Z první šňůrky bylo zřejmě zhotoveno cingulum, druhá byla asi částí bot (Chrámový poklad u sv. Víta, Pražský hrad; Bravermanová-Foltýn-Sliwka 2010). Větší množství ozdobných šňůrek pochází například z archeologických výzkumů Londýna z období pozdního 12. až počátku 15. století (Museum of London, Londýn; Crowfoot-Pritchard-Staniland 1992, 138-140).

Součástí bot mohla být tedy asi i šňůrka nalezená v hrobě jižně od hrobu Petra Parlére. Šňůrka nevykazuje žádné znaky, podle nichž by bylo možné ji přesněji datovat či určit provenienci. Lze však předpokládat, že byla $\mathrm{v}$ průběhu středověku vyrobena $\mathrm{v}$ některé $\mathrm{z}$ textilních dílen $\mathrm{v}$ Evropě, včetně českých zemí - v tom př́ípadě byl použit importovaný materiál.

\subsection{Kožený střevíc}

Dochovaly se čtyři fragmenty o rozměrech $8,5 \times 6,5 \mathrm{~cm}, 12,5 \times 8,3 \mathrm{~cm}, 5,3 \times 5,2 \mathrm{~cm}$ a $3,1 \times 1,6 \mathrm{~cm}$. Dva větší bylo možno položit tak, že ač nelícují, vytvářejí spolu tvar podešve, původně zhruba $24 \mathrm{~cm}$ dlouhé. Zhotovena byla ze dvou vrstev kůže, po jejím obvodu se dochovala řada vpichů. Další dva nalezené fragmenty, jeden větší a jeden menší,

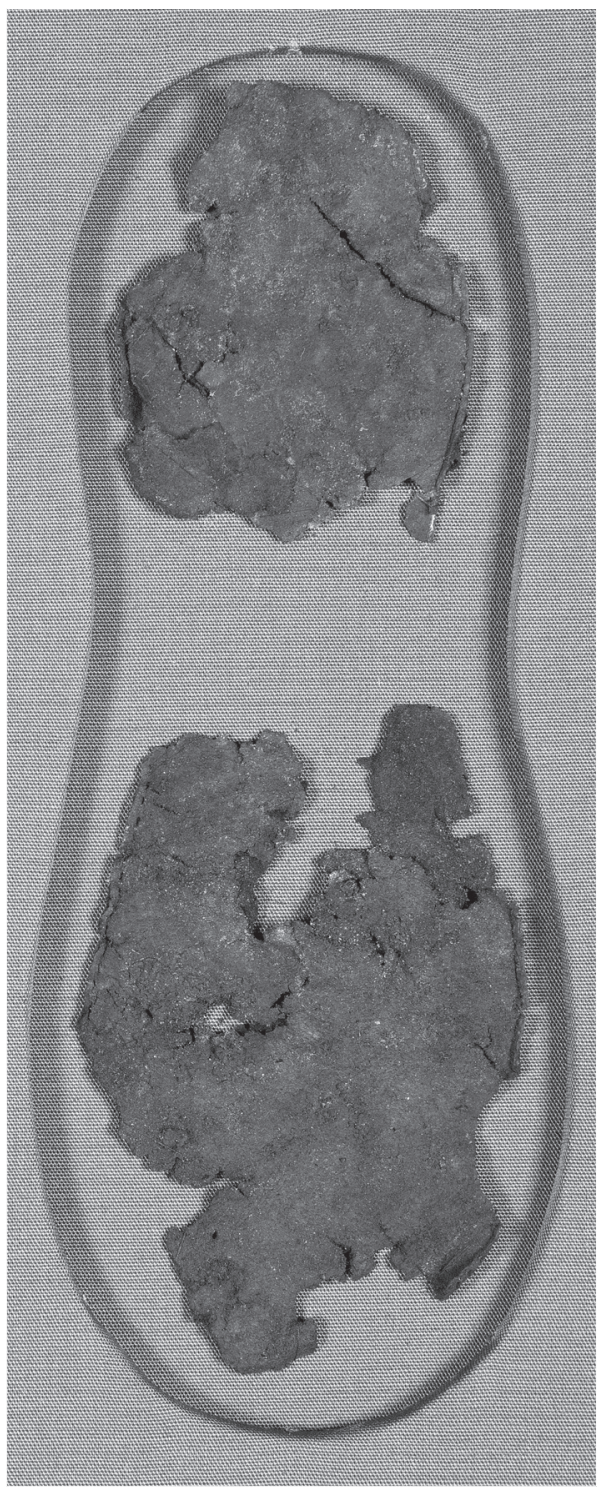

Obr. 13a. Fragmenty kožené boty tvořící podešev. @ Správa Pražského hradu, foto J. Gloc.

Abb. 13a. Die Sohle bildenden Lederschuhfragmente. (c) Verwaltung der Prager Burg, Foto J. Gloc. 
pocházejí ze svršku boty. Na obou se dochovaly části původních okrajů svírající spolu tupý úhel, vždy podél jednoho z těchto okrajů se nacházejí vyseknuté otvory ve tvaru písmene $\mathrm{V}$ (na větším fragmentu jsou zachovány dva otvory a na menším jeden), sloužící zřejmě pro protažení tkanice. Pravděpodobně se jedná o pozůstatek kolmého rozparku kdysi spojeného šněrováním, který se nacházel na vnitřní straně střevíce, dochované fragmenty se tak nalézaly v partii u kotníku. Povrch obou fragmentů je pokryt vtlačenými a hustě diagonálně položenými liniemi, přes něž šlo zlacení a ornamenty seskládané ze záseků vyrážených do kůže drobným průbojníkem ve tvaru písmene C. Kompletní výzdobu svršku nelze rekonstruovat.

Nalezené fragmenty zřejmě pocházejí z pontifikální obuvi.

Pontifikální střevíce se vyvinuly z obuvi nošené ve 4. století v Římě senátory, církevní využití je doloženo od 6. století. Výsada je nosit zpočátku patřila papežům a římským klerikům, zhruba od 8. století však čím dál tím širšímu okruhu duchovních. Přesto právo užívat liturgické odění nohou, k němuž patřily i punčochy, přináleželo nejvíce biskupům a opatům. Podle tvaru lze liturgickou obuv rozdělit do tří typů. U prvního nejstaršího typu vybíhal vpředu svršek a po stranách a vzadu byly jazyky, svázané šňůrkou prostrčenou poutky. Druhý typ se začal objevovat ve 12. století. Jazyky již byly zakrnělé, svršek získával na výšce. Třetí, nejmladší typ, vyskytující se od 13. století, sahal ke kotníkům. Jazyky zmizely, vepředu byl pouze krátký průřez či výřez usnadňující oblékání. Později se na vnitřní stranu umistoval rozparek se šněrováním, případně s knoflíčky. Jako materiál se pro liturgické obutí nejvíce používala kůže, někdy hedvábná tkanina, která však mohla potahovat kožený korpus. Výzdobu střevíců tvořily výšivky a nášivky často s geometrickými či rostlinnými prvky a stylizovanými zvířecími postavami. Vyskytovaly se i drobné vysekané dírky, které bud' oživovaly plochu anebo v nich byly upevněny malé nýtky. Hojně se také využívalo zlacení (Braun 1907, 384-424; Bravermanová-Otavská 2003; Strettiová 1956).

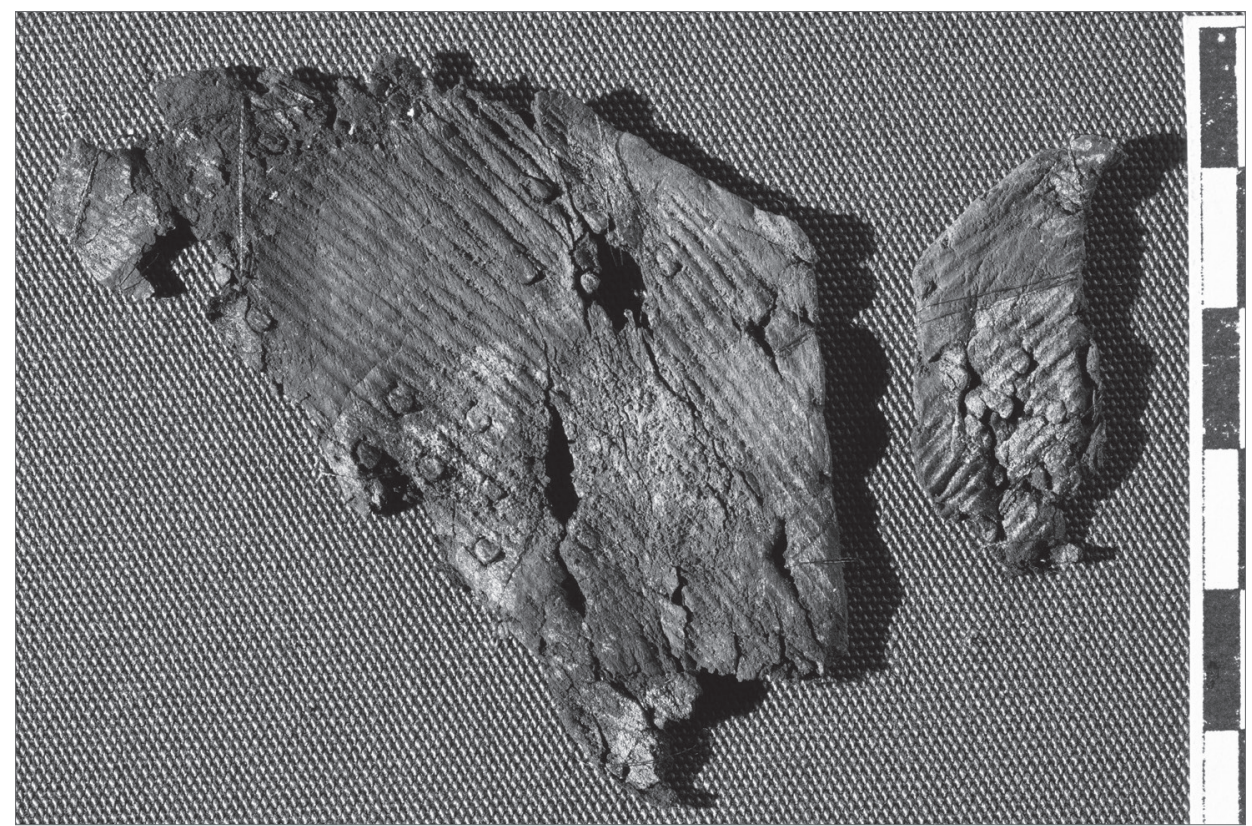

Obr. 13b. Fragmenty ze svršku kožené boty. (C) Správa Pražského hradu, foto J. Gloc.

Abb. 13b. Fragmente vom Oberteil eines Lederschuhs. (c) Verwaltung der Prager Burg, Foto J. Gloc. 
Přestože se obuv z hrobu jižně od hrobu Petra Parléře zachovala ve fragmentárním stavu, pravděpodobně spadala pod třetí typ liturgického odění nohou, zbytky rozparku s otvory pro šněrování svědčí o jeho pokročilé formě.

Kožené a zdobené pontifikální střevíce pocházejí například z pokladu parament v Castel S. Elia u Nepi, ke třetímu typu vročenému do 13. století náleží jeden z nich (Braun 1907, 410, obr. 198). Ke stejnému typu také patří střevíc datovaný do 14. století a připsaný kardinálovi Pierrovi de Luxembourg. Má po vnitřní straně rozparek, kolem jeho okrajů jsou dírky, kterými původně byla protažena šňůrka (Musée Cluny, Paříž; Schoefer-Lestoquoit 1987, 41). V Čechách z období vrcholného středověku pochází kožený střevíc nalezený v klášteře $\mathrm{v}$ Emauzích na Novém Městě pražském. Je datovaný do druhé poloviny 14. století, patří však ke druhému typu. Zřejmě náležel opatovi (Národní muzeum, Praha; Brych 1986, 17-20). Nejpodobnější analogie ke střevíci z hrobu jižně od hrobu Petra Parléře tak pochází z hrobu biskupa Mikuláše († 1258) v katedrále sv. Víta. Zbytky kožených bot třetího typu měly na vnitřní straně rozparek, u jednoho z nich se zachovalo spojení dvěma knoflíčky. Svršek byl zdoben výšivkou, možná s postavou lva (Chrámový poklad u sv. Víta, Pražský hrad; Strettiová 1956, 194).

Nález kožených střevíců, které svým tvarem odpovídají pontifikálnímu odění nohou, podporuje určení, že hrob nacházející se jižně od hrobu Petra Parléře náležel církevní osobě.

\section{Interpretace}

V nálezu pohřební výbavy bylo rozeznáno několik textilií. Hedvábný lampas je zřejmě pozůstatkem církevního oděvu, nejspíše kasule. Část rukávu z hedvábné tkaniny, u zápěstí lemovaná tkanicí zhotovenou na destičkách, může být z alby, dvě zlaté výšivky anebo alespoň jedna z nich ozdobnou parurou na ní. Pokud by jedna z výšivek nebyla aplikována na albě, mohla být svrchní částí polštáře. Fragment sametu je nejspíše zbytkem mitry, olemování rohů, cingulum, titulus či fanony mohly být vytvořeny z nalezených tkanic. Jednoznačnými součástmi ceremoniálního odění nohou výše postavených církevních hodnostářủ jsou hedvábná punčocha a kožená obuv.

Obdobně textiliemi vybavené hroby středověkých církevních hodnostářu se nacházejí např́klad v katedrále v Bamberku (Textile Grabfunde 1987) nebo v katedrále ve Špýru (Müller-Christensen 1972, 989-1024).

Textilie z hrobu jižně od hrobu Petra Parléře představují výjimečný vrcholně středověký soubor, jehož část - zlaté výšivky a kolínské tkanice - se v kolekci archeologického textilu z Pražského hradu z období vrcholného středověku dosud nenacházely. ${ }^{9}$ Je velmi pravděpodobné, že se jedná o pohřební výbavu vysoce postaveného církevního činitele, který byl uložen do hrobu před starou sakristí́ po roce 1362.

Podle písemných pramenů by do úvahy mohly přicházet dvě osobnosti, které byly podle starších zpráv pohřbeny ve svatovítské katedrále, avšak přesná poloha jejich hrobů není známa. Prvním z nich je Filibert de Montjeu, francouzský duchovní, biskup normandského města Coutances, který byl účastníkem basilejského koncilu a jako papežský legát přicestoval do Čech, aby zde jednal s utrakvisty. Dne 19. června 1439 zemřel na mor a měl být pohřben v katedrále sv. Víta v „kuoře novém" (Staré letopisy české, text V, 123), tedy v chóru Panny Marie. Z roku 1589 však existuje svědectví, podle kterého $\mathrm{v}$ tomto roce, tedy krátce před přestěhováním pohřbů do nové královské krypty, se předpokládané biskupovo tělo nacházelo poblíž panovnických ostatků, což znamená ve staré královské hrobce (Mikovec 1862, 106). Z hlediska historických okolností žádný kosterní nález neodpovídá možnosti, že by Filibertovy ostatky byly v roce 1590 vloženy do nové královské krypty (Lutovský-Bravermanová 2007), spíše tak mohly zůstat ve staré hrobce. Její východní část byla zrejmě vyhrazena duchovním (Maříková-Kubková-Herichová 2009,75-77), v 17. a 18. století je zde dokonce doloženo několik pohřbů kanovníků a arcibiskupů (Beneš 1872, 597).

9 Dosud byly dokumentovány pouze výšivky a tkanice ze souboru pohřebních výbav pražských biskupů, které jsou datované do 11.-14. století (Bravermanová 2004). 
Druhou, a to daleko pravděpodobnější možností je pohřeb Mikuláše Puchníka. Tato přední osobnost českého církevního života své doby vstoupila do dějin zejména 20. března 1393, kdy generální vikár Puchník byl zajat spolu se svými třemi kolegy v rámci sporu krále Václava IV. s arcibiskupem Janem z Jenštejna. Zajatci byli mučeni, přičemž jeden z nich, generální vikár̆ Johánek z Pomuku, pozdější sv. Jan Nepomucký, zemřel. Ostatní byli propuštěni. Po smrti pražského arcibiskupa Olbrama III. ze Škvorce 1. května 1402 byl Puchník zvolen jeho nástupcem. Jeho volba snad proběhla pod vlivem Zikmunda Lucemburského a byla vedena proti politice Václava IV. Puchníkovo zvolení bylo potvrzeno i papežem, ovšem ještě než bylo přikročeno $\mathrm{k}$ jeho vysvěcení, Puchník zemřel a 19. září 1402 byl pohřben na později neznámém místě v katedrále sv. Víta na Pražském hradě (Budský 2013, 23-24). Zjištěná datace a interpretace textilií z hrobu jižně od hrobu Petra Parlére podporuje teorii, že se jedná právě o kolekci z Puchníkova hrobu. Lze očekávat, že zvolený, avšak nevysvěcený pražský arcibiskup byl pohřben poněkud okázaleji než běžní kanovníci, avšak povědomí o tomto hrobu bylo menší než o hrobech skutečně úřadujících pražských arcibiskupů té doby. Zajímavé je i datum jeho pohřbu - pouhé tři roky po pohřbu Petra Parléře. Je tedy možné, že v této době bylo místo v sousedství Staré sakristie vnímáno jako místo pro uložení ostatků mimořádných osobností. Svou roli mohla v př́ípadě církevního pohřbu sehrát právě i blízkost Staré sakristie, jinak též kaple sv. archanděla Michaela.

Vyloučit samozřejmě nelze ani to, že pohřbeným je ve skutečnosti někdo úplně jiný, jehož jméno je dosud neznámé.

\section{Závěr}

At' už se jedná o pozůstatky pohřební výbavy Mikuláše Puchníka, nebo někoho jiného, je soubor nálezů z hrobu jižně od hrobu Petra Parléře dokladem vysoké úrovně gotického textilnictví, a to importovaného, ale možná částečně i českého původu. Přestože kolekce byla ohrožena dlouholetým uložením v nevyhovujících hrobových podmínkách a poté ve sklepení budovy ve Vikářské ulici, její restaurování a vyhodnocení významně obohatilo archeologickou sbírku Pražského hradu.

Příspěvek byl vypracován s podporou grantového projektu GA ČR 19-00166S.

\section{Př́íloha. Textilně technologický rozbor textilií z hrobu jižně od hrobu Petra Parléře}

Tkanina s fénixy, pávy a diagonálními úponky (3.1)

Technika: lampas (dutinná tkanina v základu/lampas à fond double étoffe)

Osnova

poměr: 3 hlavní osnovy a 3 páry hlavních osnov (pravidelně se spolu střídají) ku 1 vazné osnově - hlavní: hedvábí, z-zákrut, hnědá barva

- vazná: hedvábí, bez viditelného zákrutu, hnědá barva

dostava: 117-126 (nejčastěji 126) nití/cm (hlavní osnova), 13-14 nití/cm (vazná osnova)

découpure: 1 vazná osnova

Útek

poměr (pořadí v passées): 1 základní útek ku 1 vzorujícímu útku I. ku 1 vzorujícímu útku II.

- základní: hedvábí, bez viditelného zákrutu, hnědá barva

- I.: lancé, hedvábí, bez viditelného zákrutu, hnědozelená barva

- II.: lancé, pozlacený proužek živočišného podkladu obtočený kolem lněné duše (skaný zákrut $\mathrm{S} / 2$ nitě $\mathrm{s}$ neurčitelným zákrutem, hnědá barva), směr vinutí $\mathrm{S}$, zachováno fragmentárně

dostava: 21 passées/cm

découpure: 1 passée

Pevný okraj 
šířka: ca $0,6 \mathrm{~cm}$

vazba: od kraje - neurčitelná (osnova I., základní útek, vzorující útky I., II.), dutinná tkanina atlasová 4/1 (décochement 2; osnova I., základní útek), plátnová (osnova II., vzorující útky I., II.) Osnova

- osnova I.: nezachovala se, rostlinný materiál (?), patrné pouze smyčky tvořené základním útkem

- osnova II.: hedvábí, z-zákrut, hnědá barva, každá druhá párová

- osnova III.: hedvábí, bez viditelného zákrutu, hnědá barva

Nevzorovaný řezaný samet (3.2)

Technika: řezaný samet (velours coupé)

Osnova

poměr: 3 hlavní osnovy k 1 vlasové osnově

- hlavní: hedvábí, z-zákrut, hnědá barva

- vlasová: hedvábí, bez viditelného zákrutu, hnědá barva

dostava: 42 hlavních osnov/cm, 14 vlasových osnov/cm

Útek

poměr (pořadí v passées): 3 základní útky $\mathrm{k} 1$ struně

- základní: hedvábí, bez viditelného zákrutu, hnědá barva

dostava: 36 základních útků/cm, 12 strun/cm

Pevný kraj: nezachoval se

Šicí nit: hedvábí, skaný zákrut S/2 z-zákrut, hnědá barva

Nevzorovaná tkanina (3.3)

Vazba: plátnová

Osnova

hedvábí, z-zákrut, hnědá barva

dostava: 37-42, nejčastěji 39 nití/cm

Útek

hedvábí, bez viditelného zákrutu, hnědá barva

dostava: 30-40, nejčastěji 36 nití/cm

Pevný okraj: nezachoval se

Šicí nit: hedvábí, skaný zákrut S/2z, hnědá barva

\section{Tkanice}

Technika: tkaní na destičkách

Osnova

skaný zákrut $\mathrm{S} / 2$ bez viditelného zákrutu, hnědá barva

dostava: 36 nití $/ 0,6 \mathrm{~cm}$

Útek

- základní: len, bez viditelného zákrutu, hnědá barva, zachován fragmentárně

dostava: nelze určit

- vzorující: broché, kovová pozlacená lamela, hedvábná duše (s-zákrut), směr vinutí S, dochovala se především duše, lamela jen fragmentárně

Pevný okraj: zachoval se na obou stranách tkanice

Nevzorovaná tkanina (3.4)

Vazba: plátnová

Osnova

hedvábí, z-zákrut, hnědá barva

dostava: 33-38, nejčastěji 35 nití/cm

Útek 
hedvábí, bez viditelného zákrutu, hnědá barva

dostava: 25-32, nejčastěji 26 nití/cm

Pevný okraj: zachoval se na jedné straně fragmentu č. 2

osnova I.: hedvábí, z-zákrut, hnědá barva, 1 vícenásobná nit

Šicí nit: hedvábí, skaný zákrut $\mathrm{S} / 2$ bez viditelného zákrutu, hnědá barva

Výšivka s motivem žaludi̊, dubových a hlohových listů (3.5)

Svrchni tkanina

Vazba: plátnová

Osnova

hedvábí, z-zákrut, hnědá barva

dostava: 40-43 nití/cm, nejčastěji 41 nití/cm

Útek

hedvábí, bez viditelného zákrutu, hnědá barva

dostava: 48-60 nití/cm, nejčastěji 54 nití/cm

Pevný okraj: nezachoval se

Podkladová tkanina

Vazba: plátnová

Osnova

len, z-zákrut, hnědá barva

dostava: nelze určit

Útek

len, z-zákrut, hnědá barva

dostava: nelze určit

Pevný okraj: nezachoval se

Vyšívací nit I.: pozlacená stříbrná lamela s duší (len, s-zákrut, hnědá barva), směr vinutí S

Vyšívací nit II.: hedvábí, skaný zákrut S/2 bez viditelného zákrutu, hnědá barva

Nit zachytávající vyšívací nitě: hedvábí, skaný zákrut S/2 bez viditelného zákrutu, hnědá barva

Výšivka s motivem vinných listi̊ (3.6)

Svrchni tkanina

Vazba: plátnová

Osnova

hedvábí, z-zákrut, hnědá barva

dostava: 40-43 nití/cm, nejčastěji 41 nití/cm

Útek

hedvábí, bez viditelného zákrutu, hnědá barva

dostava: 48-60 nití/cm, nejčastěji 54 nití/cm

Pevný okraj: nezachoval se

Podkladová tkanina

Vazba: plátnová

Osnova

len, z-zákrut, hnědá barva

dostava: $14-15$ nití/cm

Útek

len, z-zákrut, hnědá barva

dostava: $12-13$ nití/cm

Pevný okraj: nezachoval se

Vyšívací nit: pozlacená stř́ibrná lamela s duší (len, s-zákrut, hnědá barva), směr vinutí S

Nit zachytávající vyšívací nit: hedvábí, skaný zákrut S/2 bez viditelného zákrutu, hnědá barva 


\section{Tkanice s mandorlami a kosočtverci (3.7)}

Technika: samitum

Osnova

poměr: 2 hlavní osnovy ku 1 vazné osnově

- hlavní: len, skaný zákrut $\mathrm{S} / 2$ bez viditelného zákrutu, světle hnědá barva

- vazná: hedvábí, skaný zákrut S/2z, hnědá barva

dostava: 28 nití/cm (hlavní osnova), 14 nití/cm (vazná osnova)

découpure: 2 hlavní osnovy

Útek

poměr (pořadí v passées): 1 útek I. ku 1 útku II. ku 1 útku III. nebo 1 útek I. ku 1 útku III. (I., II., III. nebo I. III.)

- I.: lancé, pozlacená kovová lamela obtočená kolem hedvábné duše (s-zákrut, hnědá barva), směr vinutí $\mathrm{S}$

- II.: broché, pozlacená kovová lamela obtočená kolem hedvábné duše (s-zákrut, hnědá barva), směr vinutí $\mathrm{S}$

- III.: lancé, len, skaný zákrut S/2 bez viditelného zákrutu, tmavě hnědá až černá barva

dostava: 19-26 passées/cm

découpure: 1 passée

Pevný okraj: zachoval se na obou stranách tkanice

Vyšívací nit: hedvábí, skaný zákrut $\mathrm{S} / 2$ bez zákrutu, tmavá barva

\section{Tkanice s kosočtverci a písmenem (3.8)}

Technika: samitum

Osnova

poměr: 1 hlavní osnovy ku 1 vazné osnově

- hlavní: len, skaný zákrut $\mathrm{S} / 2$ bez viditelného zákrutu, hnědá barva

- vazná: hedvábí, skaný zákrut $\mathrm{S} / 2$ bez viditelného zákrutu, hnědá barva

dostava: 32 nití/cm (hlavní osnova), 32 nití/cm (vazná osnova)

découpure: 1 hlavní osnova

Útek

poměr (pořadí v passées): 1 útek I. ku 1 útku II. ku 1 útku IV. nebo 1 útek I. ku 1 útku III. Ku 1 útku IV. nebo 1 útek 1 ku 1 útku IV. (I., II., IV. nebo I. III. IV. nebo 1. IV.)

- I.: lancé, pozlacená kovová lamela obtočená kolem hedvábné duše (s-zákrut, hnědá barva), směr vinutí $\mathrm{S}$

- II.: broché, ztrojený, hedvábí, skaný zákrut S/2 z-zákrut, světle hnědá barva

- III.: broché, ztrojený, hedvábí, skaný zákrut S/2 z-zákrut, hnědá barva

- IV.: lancé, len, z-zákrut, hnědá barva

dostava: 28 passées $/ \mathrm{cm}$

découpure: 1 passée

Šicí nit I.: hedvábí, skaný zákrut $\mathrm{S} / 2$ bez zákrutu, tmavá barva

Šicí nit II.: hedvábí, skaný zákrut $\mathrm{S} / 3$ bez zákrutu, tmavá barva

\section{Tkanice s lomenými liniemi (3.9)}

Technika: samitum

Osnova

poměr: 6 hlavních osnov ku 4 vazným osnovám

- hlavní: len, skaný zákrut $\mathrm{S} / 2$ bez viditelného zákrutu, světle hnědá barva

- vazná: hedvábí, skaný zákrut $\mathrm{S} / 2$ bez viditelného zákrutu, hnědá barva

dostava: 24 nití/cm (hlavní osnova), 16 nití/cm (vazná osnova)

découpure: 6 hlavních osnov

Útek 
poměr (pořadí v passées): 2 útky I. ku 2 útkům II. (I., I., II., II.)

- I.: lancé, zdvojený, pozlacená kovová lamela obtočená kolem hedvábné duše (s-zákrut, hnědá barva), směr vinutí $S$

- II.: lancé, len, z-zákrut, tmavě hnědá barva

dostava: 18 passées/cm

découpure: 1 passée

\section{Tkanice (3.10)}

Tkalcovská vazba: odvozená plátnová vazba - pravidelný podélný ryps $2 / 2$ (louisine)

Osnova

pozlacená kovová lamela, hedvábná duše (s-zákrut, hnědá barva), směr vinutí S

dostava: 34 nití/cm

Útek

pozlacená kovová lamela, hedvábná duše (s-zákrut, hnědá barva), směr vinutí S

dostava: 7 nití/cm

\section{Šn̆ưrka (3.11)}

Nit šňůrky: hedvábí, skaný zákrut $S / 2$ bez viditelného zákrutu, hnědá barva

Šicí nit: hedvábí, skaný zákrut $\mathrm{S} / 2$ bez viditelného zákrutu, hnědá barva

\section{Literatura}

BENEŠ, F. J., 1872: Hrobka pod hl. oltářem v hl. chrámu sv. Víta v Praze, Světozor 6, 597.

BENEŠOVSKÁ, K., 1994: Architektura. In: Katedrále sv. Víta. K 650. výročí založení (Merhautová, A., ed.), 25-66. Praha.

BLÖCHER, H., 2012: Die Mitren des hohen Mittelalters. Bern, Abegg-Stiftung.

BRAUN, J., 1907: Die liturgische Gewandung im Occident und Orient nach Ursprung und Entwicklung, Verwendung und Symbolik. Feiburg im Breisgau.

BRAVERMANOVÁ, M., 1999: Textilie z hrobu Matyáše z Arrasu a Petra Parléře - Textilien aus dem Grab des Matthias von Arras und des Peter Parler, AH 24, 421-438.

- 2004: Hroby pražských biskupů v katedrále sv. Víta na Pražském hradě. Předběžné sdělení - Gräber der Prager Bischöfe in der St. Veit Kathedrale auf der Prager Burg, AH 29, 599-615.

- 2006: Pohřební oděv Jana Zhořeleckého z královské hrobky v katedrále sv. Víta na Pražském hradě - Begräbnisgewand von Jan Zhořelecký aus der königlichen Gruft im Sankt-Veits-Dom in der Prager Burg, AH 31, 403-412.

- 2007: Pohřební výbava pražského biskupa Mikuláše - Die Grabausstattung des Prager Bischofs Nikolaus, AH 32, 477-489.

- 2012: Mitra zvaná svatovojtěšská. In: Svatovítský poklad. Katalog stálé výstavy v kapli sv. Kříže na Pražském hradě (Kyzourová, I., ed.), 43. Praha.

BRAVERMANOVÁ, M.-BŘEZINOVÁ, H., 2014: Tkanice z pohřebních šatů jedné z českých královen zhotovená technikou tkaní na destičkách - Ein mit Brettchentechnik gewebtes Band vom Grabgewand einer böhmischen Königin, AH 39, 299-313.

BRAVERMANOVÁ, M.-BŘEZINOVÁ, H., 2016: Hedvábné textilie. In: Březinová, H. - Kohout, D. et al., Středověké textilní a barvířské technologie. Soubor textilních fragmentů z odpadních vrstev z Nového Města pražského. Archeologický ústav AV ČR, 113-145. Praha.

BRAVERMANOVÁ, M.-FOLTÝN, D.-SLIWKA, A., 2010: Mitra z hrobu „ctihodného Bernarda, biskupa pražského“ - The mitre from the grave of „venerable Bernard, the Prague bishop“, Medievalia historica Bohemica 13, 7-45.

BRAVERMANOVÁ, M.-OTAVSKÁ, V., 2003: Pohřební střevíc pravděpodobně biskupa Šebíře - Der bergräbnisschuh wahrscheinlich des Bischofs Šebír (Severus), AH 28, 503-524. 
BRYCH, V., 1986: Středověké nálezy z Emauzského kláštera ve sbírkách Národního muzea v Praze, ČNM A CLV, 13-28.

BUDSKÝ, D., 2013: Mikuláš Puchník, život a právnické dílo. Disertační práce, Katolická teologická fakulta UK, Praha.

CROWFOOT, E.-PRITCHARD, F.-STANILAND, K., 1992: Textiles and clothing (c. 1150 - c. 1450). Medieval finds from excavations in London. London.

DURIAN-RESS, S., 1986: Meisterwerke mittelalterlicher Textilkunst aus dem Bayerichen Nationalmuseum. Auswahlkatalog. München - Zürich.

JEHLE, M.-WETTER, E., edd., 2005: Liturgische Gewänder und andere Paramante im Dom zu Brandenburg. Abegg-Stiftung, Domstift Brandenburg.

KLETZL, O., 1931: Die Grabsteine der Dombaumeister von Prag. In: Zeitschrift für bildende Kunst. Kunstchronik vol. 64 (1930/31), 175-180. Leipzig.

KLOUDOVÁ, R.-VRABCOVÁ, A., 2018: Konzervování textilních fragmentů z katedrály sv. Víta z hrobu jižně od Petra Parléře. Nepublikovaná restaurátorská zpráva, rkp. ulož. v dokumentaci oddělení uměleckých sbírek Správy Pražského hradu, inv. č. PHA 223.

LUTOVSKÝ, M.-BRAVERMANOVÁ, M., 2007: Hroby a hrobky našich knížat, králů a prezidentů. Praha.

MARGOLD, F. X., 1928: Stavební deníky svatovítské, 1928 (VII. 12) - 1928 (XI. 30.), nepublikováno, uloženo v APH pod signaturou A 420/2013.

MARTÍNEK, R.-OPPELTOVÁ, J.-SEDINÍK, T.-SLAVÍKOVÁ, V.-ŠTĚPÁNKOVÁ, D., 2008: Záchrana a inventarizace drobných církevních fondů. Archiválie, knihy, notový materiál a liturgické textilie. Olomouc.

MAŘÍKOVÁ-KUBKOVÁ, J.-HERICHOVÁ, S., 2009: Katedrála sv. Víta, Václava, Vojtěcha a Panny Marie. Castrum Pragense 10 - Archeologický atlas Pražského hradu. Díl I. Katedrála sv. Víta - Vikářská ulice. Praha.

MIKOVEC, F. B., 1862: Krypta královská na hradě Pražském a mrtvola biskupa Filiberta Coutanceského. Lumír, Týdenník belletristický a archiv pro dějepis 12, 106-107.

MÜLLER-CHRISTENSEN, S., 1972: Die Gräber im Königschor. In: Der Dom zu Speyer Die Kunstdenkmäler von Rheinland - Pfalz 5 (Kubach, H. E., ed.), 923-1024. München.

ODSTRČILOVÁ, S., 2020: Zpráva o průzkumu tkanice dalmatiky Václava IV. Nepublikovaná zpráva, rkp. ulož. v dokumentaci oddělení uměleckých sbírek Správy Pražského hradu, inv. č. PHA 5.

OTAVSKÝ, K.-WARDWELL, A. E., 2011: Mittelalterliche Textilien II. Zwischen Europa und China. Bern, Abegg-Stiftung.

PODLAHA, A., 1930: Ilustrovaný katalog pokladu chrámu sv. Víta v Praze. Praha.

PODLAHA, A.-ŠITTLER, E., 1903: Chrámový Poklad u Sv. Víta v Praze. Praha.

SCHOEFER, M.-LESTOQUOIT, D., 1987: The restoration of a Twelfth-Century Liturgical Sandal at the Musée Historique des Tissus in Lyons. The conservation of Tapestries and Embroideries. Proceedings of Meetings at the Institut Royal du Patrimoine Artistique. Brussels, Belgium, September 21-24, 1987.

SCHUETTE, M.-MÜLLER-CHRISTENSEN, I., 1964: The Art of Embroidery. London.

SPIES, N., 2000: Ecclesiastical Pomp \& Aristocratic Circumstance: A Thousand Years of Brocaded Tabletwoven Bands. Maryland.

SPORBECK, G., 2001: Die Liturgischen Gewänder 11. bis 19. Jahrhundert. Bestandskatalog. Bestandskata$\log$ des Museum Schnütgen Stoffbilderbuch - 1. September 2001. Köln.

STARÉ LETOPISY ČESKÉ: Prameny dějin českých, nová řada, II. díl. Staré letopisy české (Texty nejstarší vrstvy). In: Fontes rerum Bohemicarum. Searia nova, tomus II (Černá, A. M.-Č́ornej, P.-Klosová, M., edd.). Praha 2003.

STRETTIOVÁ, O., 1956: Pontifikální střevíce románské doby. Umění věků. Sborník věnovaný k 70. narozeninám J. Cibulky (Líbal, D.-Vilímková, M., edd.), 192-195. Praha.

TEXTILE GRABFUNDE 1987: Textile Grabfunde aus der Sepultur des Bamberger Domkapitels. Internationales Kolloquium, Schloss Seehof, 22./23. April 1985 (Petzet, M., ed.). Bayerisches Landesamt für Denkmalpflege. München.

VÝROČNÍ ZPRÁVA 1929: Výroční zpráva Jednoty pro dostavění hlavního chrámu sv. Víta na Hradě pražském za správní rok 1929. Praha. 
WARDWELL, A. E., 1976-1977: The Stylistic Development of 14th- and 15th-Century Italia Silk Design, Aachener Kunstblatter 47, 177-226.

WETTER, E., 2001: Böhmische Bildstickerei um 1400. Die Stiftungen in Trient, Brandenburg und Danzig. Berlin.

- 2006: Výšivky na dalmatikách se scénami z legendy o sv. Vigiliovi. In: Karel IV. Císař z boží milosti. Kultura a umění za vlády Lucemburků 1310-1437. Katalog výstavy (Fajt, J., ed.), 444-446. Praha.

- 2012: Mittelalterliche Textilien III. Stickerei bis um 1500 und figürlich gewebte Borten. Bern, Abegg-Stiftung.

WILCKENS, L. von, 1991: Die textilen Künste. Von der Spätantike bis um 1500. München.

- 1992: Mittelalterliche Seidenstoffe. Bestandskatalog XVIII des Kunstgewerbemuseums. Berlin.

ZEMINOVÁ, M., 1974: K původu tzv. třeboňského antependia, ČNM III-IV, 118-151.

\section{Zusammenfassung}

\section{Textilien aus dem sich südlich von Peter Parlers Grab im Veitsdom auf der Prager Burg befindenden Grab}

Auf der Prager Burg befindet sich eine einzigartige Kollektion archäologischer Textilien, die bei verschiedenen in den letzten über hundert Jahren auf der Prager Burg durchgeführten Grabungen und Bauaktivitäten entdeckt wurden. Diese Kollektion wurde vor kurzem um einen Komplex bereichert, der die Überreste von Luxustextilien enthielt, zu denen es in den Sammlungen der Prager Burg zu einigen bislang keine Parallelen gibt. Interessant ist auch die Entdeckungsgeschichte und die Interpretation des ganzen Komplexes, der in jüngster Vergangenheit eine Restaurierung durchgemacht hat.

Der Komplex wurde 2016 bei der Räumung des alten Kellerdepots des Archäologischen Instituts der Akademie der Wissenschaften der Tschechischen Republik in der Vikářská-Straße auf der Prager Burg entdeckt und der Abteilung für Kunstsammlungen in der Verwaltung der Prager Burg übergeben. Es handelte sich um die Überreste mehrerer Arten von Prachttextilien und um Lederreste, die zwischen alten Fensterscheiben eingelagert worden waren. Anhand der erhalten gebliebenen alten Beschriftungen konnte nachvollzogen werden, dass es sich um Überreste einer Grabausstattung handelt, die aus einem Grab gehoben wurden, das sich südlich vom Grab des Erbauers des Doms Peter Parler im Chorumgang des Veitsdoms auf der Prager Burg befindet. Die Gräber der beiden ältesten Erbauer des Doms Matthias von Arras und Peter Parler wurden im August 1928 bei im Zusammenhang mit der Fertigstellung des Veitsdoms erfolgten Bauarbeiten entdeckt und untersucht. In ihrer Nachbarschaft wurden noch weitere Gräber entdeckt, jedoch fand man dem erhalten gebliebenen Grabungstagebuch nach in keinem von ihnen eine solche Grabausstattung, die mit den aus dem südlich von Peter Parlers Grab gelegenen Grab gehobenen Textilüberresten vergleichbar wären. Im Unterschied zu den Gräbern der Erbauer des Doms war nicht bekannt, wer in besagtem Grab begraben wurde, weswegen an den Funden wahrscheinlich kein Interesse bestand und sie im Depot eingelagert und für weitere 90 Jahre vergessen wurden. In den Jahren 2017-2018 wurde der Fundkomplex restauriert sowie erstmals ausgewertet und interpretiert.

Von den gefundenen Textilien können zwei Fragmente eines in Lampastechnik gewebten Seidenstoffs an erster Stelle genannt werden. Der ganze Stoff war von einem mit Gold- und Buntfäden eingewebtem Muster bedeckt. Auf dem Fond mit parallel verlaufenden leicht gewellten und mit kleinen rosettenförmigen Blüten und weiteren Blättern versehenen Ranken befinden sich aufsteigende Pfaue und herabfliegende Phönixe (Fenghuans). Der Stoff kann als aus Italien oder aus dem Vorderen Orient und aus der Zeit des zweiten bis dritten Viertels des 14. Jahrhunderts stammend bestimmt werden. Im Hinblick auf die Fundumstände kann man annehmen, dass aus dem Stoff ein Kirchengewand, vielleicht eine Kasel genäht wurde. 
Ferner wurden vier Fragmente eines ungemusterten Seidensamts gefunden. Hinsichtlich der Gesamtinterpretation des Komplexes ist es wahrscheinlich, dass der Samt von einer Mitra stammt, dem entspricht auch die Auswertung der erhaltenen Nähdetails. An dem Samt ist der Abdruck eines aufgenähten Streifens eines anderen Stoffs erhalten geblieben, im Falle einer Mitra würde es sich um ein Saumband handeln. Im Komplex erhalten geblieben sind die Überreste vier verschiedener solcher, besonders aus seidenen Goldfäden gewebter Bänder. Ein Typ trägt ein anspruchsvolles plastisches Motiv von Mandorlen mit Eicheln und Flammen, auf dem Fragment eines anderen Bandes ist offensichtlich auch der mit Buntfäden eingewebte Buchstabe eines gotischen M erhalten geblieben. Die Bänder können in die Zeit des Hochmittelalters datiert werden, und ihre Entstehung lässt sich durchweg in Spezialwerkstätten in Köln am Rhein oder Umgebung legen.

Als Überrest einer Albe kann das Fragment eines Ärmels bezeichnet werden, das aus einem in Leinenbindung gewebten feinen Stoff angefertigt wurde. Die Ärmelmanschette wird von einem schmalen Band gesäumt, das mit der Technik des Brettchenwebens aus Seidenfäden mit erhaltenen Goldresten gewebt wurde, die ein enfaches geometrisches Muster bilden. Obwohl die Verwendung von Seide als Material für Alben relativ außergewöhnlich ist, werden Seidenalben in den Inventaren des Domschatzes bei St. Veit aus den Jahren 1387 und 1441 ausdrücklich erwähnt.

Mit der in Betracht gezogenen Seidenalbe können auch die Überreste zweier Stickereien zusammenhängen, die auf dem aus feinem Seidenleinen bestehenden Stickgrund in der Anlegetechnik gefertigt wurden. Die erste Stickerei hatte ein rechteckiges Mittelfeld, das zu einem Quadratnetz unterteilt wurde. Jedes Quadrat enthält vier gleichgerichtete fächerartige Lünetten, jeweils zwei und zwei untereinander. Die Lünetten werden von einem stilisierten, an Weißdorn erinnerndes Blatt gefüllt. Das Mittelfeld ist an den Rändern mit einer breiten Bordüre gesäumt. Durch ihre Mitte verläuft eine Ranke, aus welcher Eichenblätter und Eicheln herauswachsen. Alle Motive wurden mit goldenem Stickgarn angefertigt, nur die Blattaderung und die eigentlichen Eicheln mit buntem Stickgarn. Bei der zweiten Stickerei ist nur eine Randbordüre von rechteckiger Form erhalten geblieben, das Mittelfeld fehlt. Aus der Ranke schlagen Weinrebenblätter aus, diese Elemente verfügen lediglich über eine mit goldenem Garn gestickte Umrisslinie. An beiden Seiten ist eine kleinere Ranke mit stilisierten Blättern. Die Stickereien sind wahrscheinlich eine böhmische Arbeit aus der zweiten Hälfte des 14. Jahrhunderts und konnten auf der in Betracht gezogenen Albe als Paruren appliziert worden sein.

Bemerkenswert ist der Fund eines beträchtlichen, aus zwei Teilen genähten Strumpffragmentes aus Seidenleinen. Die nächste Analogie zu dem aus dem südlich von Peter Parlers Grab gelegenen Grab stammenden Strumpf ist ein Strumpf mit fast identischem Schnitt, der ebenfalls 1928 im Veitsdom im Grab von Bischof Nikolaus († 1258) gefunden wurde. Der Fund eines solchen Strumpfes in dem südlich von Peter Parlers Grab gelegenen Grab ist ein vielsagender Beleg für die Hypothese, dass das Grab einer hochgestellten kirchlichen Person gehörte.

Die vier Lederfragmente stammen offensichtlich von Pontifikalschuhen. Die beiden größeren formen die Sohle, die beiden kleineren sind offensichtlich Überreste des Oberleders, da sie Reste einer vergoldeten und gestanzten Verzierung sowie Schnürsenkellöcher aufweisen. $\mathrm{Zu}$ den Schuhen gehörte auch eine erhalten gebliebene, in Fingerschlaufentechnik hergestellte Seidenschnur.

Den gewonnenen Erkenntnissen nach kann man in Erwägung ziehen, dass es sich um die Grabausstattung eines hochgestellten kirchlichen Amtsträgers handelt, der nach 1362 vor der alten Sakristei ins Grab gelegt wurde. Von den in Frage kommenden Persönlichkeiten erscheint als am wahrscheinlichsten die Person von Nikolaus Puchnik $(\dagger 1402)$, der einige Monate nach seiner Ernennung zum Prager Erzbischof starb und am 19. September 1402 an einem später unbekannten Ort im Veitsdom auf der Prager Burg beigesetzt wurde. Es sei dahingestellt, ob es sich um die Überbleibsel der Grabausstattung von Nikolaus Puchník oder einer anderen Person handelt, der Fundkomplex aus dem südlich von Peter Parlers Grab gelegenen Grab ist ein Beleg für das hohe Niveau der gotischen Textilkunst, und zwar importierter, möglicherweise aber teilweise auch böhmischer Herkunft. 
Der vorliegende Beitrag wurde mithilfe des Förderprojektes GA ČR 19-00166S ausgearbeitet.

PhDr. Milena Bravermanová, Archeologický ústav AV ČR, Praha, v. v. i., Letenská 4, 11801 Praha 1, Česká republika,milena.bravermanova@seznam.cz

Mgr. Jan Vlček, Správa Pražského hradu, Hrad, I. nádvoří 1, 11908 Praha 1, Česká republika,jan.vlcek@hrad.cz

Romana Kloudová, restaurátorka, Česká republika,kloudovar@seznam.cz

Alžběta Vrabcová, restaurátorka, Česká republika,vrabcovaa@seznam.cz

Toto dílo lze užít v souladu s licenčními podmínkami Creative Commons BY-NC-ND 4.0 International (https://creativecommons.org/licenses/by-nc-nd/4.0/legalcode). Uvedené se nevztahuje na díla či prvky (např. obrazovou či fotografickou dokumentaci), které jsou v díle užity na základě smluvní 
